The University of San Francisco

USF Scholarship: a digital repository @ Gleeson Library |

Geschke Center

Environmental Science

College of Arts and Sciences

2015

\title{
Low Carbon Development for Cities: Methods and Measures
}

Stephanie Ohshita

University of San Francisco, sbohshita@usfca.edu

NZhou

L Price

D Fridley

N Khanna

See next page for additional authors

Follow this and additional works at: http://repository.usfca.edu/envs

Part of the Environmental Health and Protection Commons

\section{Recommended Citation}

Ohshita, S.B., Zhou, N., Price, L., Fridley, D., Khanna, N., Hong, L.X., Lu, H.Y., Fino-Chen, C., He, G. (2015). Low Carbon

Development for Cities: Methods and Measures. In J.Y. Yan (Ed.), Handbook of Clean Energy Systems (3565-3587). London: Wiley.

This Book Chapter is brought to you for free and open access by the College of Arts and Sciences at USF Scholarship: a digital repository @ Gleeson Library | Geschke Center. It has been accepted for inclusion in Environmental Science by an authorized administrator of USF Scholarship: a digital repository@Gleeson Library | Geschke Center. For more information, please contact repository@usfca.edu. 
Authors

Stephanie Ohshita, N Zhou, L Price, D Fridley, N Khanna, L X. Hong, H Y. Lu, C Fino-Chen, and G He 


\title{
Chapter 32
}

\section{Low Carbon Development for Cities: Methods and Measures}

\author{
Stephanie Ohshita ${ }^{1,2}$, Nan Zhou ${ }^{1}$, Lynn Price ${ }^{1}$, David Fridley ${ }^{1}$, \\ Nina Khanna ${ }^{1}$, Lixuan Hong ${ }^{1}$, Hongyou Lu ${ }^{1}$, Cecilia Fino-Chen ${ }^{1}$, and \\ Gang $\mathbf{H e}^{1,3}$ \\ ${ }^{1}$ Lawrence Berkeley National Laboratory, Berkeley, CA, USA \\ ${ }^{2}$ University of San Francisco, San Francisco, CA, USA \\ ${ }^{3}$ University of California, Berkeley, CA, USA
}

\section{INTRODUCTION: LOW CARBON DEVELOPMENT OF THE CITY}

Cities consume more than $60 \%$ of global energy and that share is expected to rise with the rapid rate of urbanization now underway (van der Hoeven, 2012). Cities' energy consumption, along with the reshaping and resurfacing of land and the food and other resources they demand, lead to a similarly large share of global greenhouse gas (GHG) emissions, carbon-based and otherwise. With cities playing a crucial role in sustainable energy and climate systems, this chapter examines emerging efforts by cities around the world to shift to a development pattern with less energy and less carbon.

As relatively new concepts, the terms low carbon city and low carbon development have definitions that are still emerging. From an economic development perspective, the World Bank (2012) posits: "The overall objective of a low carbon city is to significantly reduce its carbon footprint in ways that do not compromise a city's economic development potential." This definition frames the pursuits of economic development and lowering carbon (i.e., reducing GHG emissions) as potentially conflicting pursuits, rather than viewing the economy as a part of (and dependent on) a healthy natural environment. In a primer on low carbon development, Urban and Nordensvärd (2013) define low carbon development as "... a development model that is based on climate-friendly

Handbook of Clean Energy Systems. Edited by Jinyue Yan.

(C) 2015 John Wiley \& Sons, Ltd. ISBN: 978-1-118-38858-7. low carbon energy and follows principles of sustainable development, makes a contribution to avoiding dangerous climate change and adopts patterns of low carbon consumption and production." This definition gives first attention to decarbonizing energy supply, and then to demand (consumption and production), in the context of sustainability. With a focus on the city, Zhou et al. (2011) define a low carbon city as "... a city that is actively and significantly lowering carbon emissions, even as its economy is maturing." This definition hones in on GHG emissions and suggests that in order to claim the title of "low carbon city," urban economies at any stage of development must be working toward substantial decarbonization on all fronts.

None of these definitions state a universal quantitative target, as low carbon development is a process that cities are undertaking from different starting points and circumstances. Nevertheless, we can look at scenarios of GHG emissions, desired climate attributes, and human population to consider: When does less become "low," and how can a city be considered "low carbon?" For a chance at a desirable climate with no more than $2^{\circ} \mathrm{C}$ global average warming, an 80\% reduction in GHG emissions from 1990 to 2050 in industrialized countries is the oft-cited target (Intergovernmental Panel on Climate Change, IPCC, 2007). A number of cities have adopted this $80 \%$ reduction target, including London, Hamburg, Toronto, and Chicago (CDP, 2012).

At the same time that dramatic carbon reductions are needed in absolute terms, population is expected to continue 
to grow, making the goal of "low carbon" even more challenging. Calthorpe (2011), taking into account population growth and the $80 \%$ reduction target, estimates that the average American will have to reduce to $2.7 \mathrm{tCO}_{2 \mathrm{e}}$ per person by the year 2050 , dropping to $12 \%$ of the 2005 per capita level. For comparison, the average American GHG emissions in 2012 were $16.4 \mathrm{tCO}_{2 \mathrm{e}}$ per capita, more than twice as high as the average European ( $7.4 \mathrm{tCO}_{2 \mathrm{e}}$ per capita) and a typical Chinese citizen (7.1 $\mathrm{tCO}_{2 \mathrm{e}}$ per capita; EDGAR, 2013). While the variation across cities globally and within each country makes it difficult to set a single absolute value that defines a low carbon city, the emission and population trends point toward the need for dramatic savings in urban carbon.

"Carbon" in this chapter is used as a convenient shorthand for the two major, carbon-based GHGs emitted by human activities: carbon dioxide $\left(\mathrm{CO}_{2}\right)$ and methane $\left(\mathrm{CH}_{4}\right)$. Energy use and land use-for city functions and food production-are the main activities driving these emissions. Activities in emit six of the human-generated GHGs recognized by international agreements (including those that do not contain carbon): $\mathrm{CO}_{2}, \mathrm{CH}_{4}$, nitrous oxide $\left(\mathrm{N}_{2} \mathrm{O}\right)$, sulfur hexafluoride $\left(\mathrm{SF}_{6}\right)$, hydroflourocarbons (HFCs), and perflourocarbons (PFCs) (UNFCCC, 1997). $\mathrm{N}_{2} \mathrm{O}$ is often emitted along with $\mathrm{CH}_{4}$ from fertilizer and manure in agricultural operations. The remaining three fluorinated GHGs, which have a high global warming potential and long atmospheric lifetime, come from distinctly different sources and do not occur naturally (US EPA, 2013a). Sources of $\mathrm{SF}_{6}$ include electrical systems, semiconductor processing, and magnesium production. Refrigeration, semiconductor manufacturing, and aluminum smelting emit HFCs, and PFCs come from aluminum and semiconductor production. This chapter focuses on $\mathrm{CO}_{2}$ and $\mathrm{CH}_{4}$.

Following the introduction of a low carbon city, we begin with metrics to articulate low carbon development in more specific ways across city sectors. We then characterize key steps for low carbon development. Next are methods for tracking energy use and carbon emissions, as an inventory is a foundational component for action. We then examine city targets informed by the inventory, and the connection of those targets to policy measures. The remainder of the chapter is devoted to examples of policy measures that cities are pursuing to save energy and carbon.

\section{METRICS FOR LOW CARBON CITIES}

In this exploratory time of shaping low carbon cities, multiple metrics and indicator systems are in development around the globe, from individual cities and city consortiums such as the C40 Cities Climate Leadership Group ${ }^{1}$ to international economic organizations such as the World Bank
(2010, 2012). Although no international standard exists yet, there are common elements: quantitative metrics for defining and measuring the extent of low carbon development in a city and qualitative indicators for tracking progress in low carbon city management. The quantitative metrics may be citywide (aggregate) indicators or sector-specific (disaggregated) indicators, for example, citywide $\mathrm{tCO}_{2 \mathrm{e}}$ emissions per capita or kJ energy use per $\mathrm{m}^{2}$ floor area in commercial buildings (Price et al., 2012). Qualitative indicators can characterize or track the status of low carbon initiatives, such as the establishment of a city climate task force or the implementation of strong building energy efficiency standards (CDP, 2011, 2012). Quantitative and qualitative metrics may be combined into unitless indices or composite scores that enable comparison and ranking across cities, such as the Green City Index. ${ }^{2}$

Table 1 presents a selection of quantitative metrics (indicators) being utilized by multiple organizations to characterize low carbon cities. These include aggregate and sector-specific metrics of city activities, infrastructure, economy, energy, and demographics that influence GHG emissions. Pertinent city sectors include power and heat, industrial, public and commercial buildings, residential buildings, transportation, water and wastewater, waste management, and agriculture and land use.

Aggregate metrics are useful in providing an overall characterization of a city in comparison to others. For example, comparison of economic carbon intensity, $\mathrm{CO}_{2 \mathrm{e}}$ emitted per unit of GDP produced (or vice versa), shows Paris with $112 \mathrm{ktCO}_{2 \mathrm{e}}$ per US\$ billion and Toronto with $282 \mathrm{ktCO}_{2 \mathrm{e}}$ per US\$ billion (2005 data; World Bank, 2010). A look at these and other cities reveals that European cities generally have lower carbon economies than North American cities. Chinese cities typically have the highest carbon economies, for example, Beijing weighs in with $1107 \mathrm{ktCO}_{2 \mathrm{e}}$ per US\$ billion (World Bank, 2010).

To discern the reasons for these differences, and identify actions for low carbon development, more detailed, sectorspecific indicators are needed, such as shares of energy or carbon in each economic sector or the carbon intensity of electricity. For example, Chinese cities and provinces generally have a very high share of energy-intensive industry in their economies; Beijing has nearly $40 \%$ of its economy in the secondary (industrial) sector (NBS, 2009). Recognizing the strong influence of economic structure highlighted by this metric, Chinese cities are encouraged to shift away from energy-intensive industry to lower-carbon service sector businesses as part of the 12th Five-Year Plan (State Council, 2003).

Examining activity- and energy-based indicators and carbon-based indicators provides more insight into the driving forces behind a city's GHG emissions. For example, 
Table 1. Metrics for low carbon cities.

\begin{tabular}{|c|c|c|}
\hline Sector & Low Carbon Metrics (Indicators) & \\
\hline \multirow[t]{3}{*}{ City-wide (aggregated) } & Primary energy per unit GDP & $\mathrm{CO}_{2}$ per unit GDP \\
\hline & Primary energy per capita & $\mathrm{CO}_{2}$ per capita \\
\hline & & Economic carbon efficiency $\left(\mathrm{GDP} / \mathrm{CO}_{2}\right)$ \\
\hline \multirow[t]{4}{*}{$\begin{array}{l}\text { Structural and socio- } \\
\text { economic }\end{array}$} & $\begin{array}{l}\text { Share of industrial or tertiary sector in the economy (\% } \\
\text { GDP) }\end{array}$ & Income distribution \\
\hline & Share of energy in each economic sector & Income per capita \\
\hline & & Housing affordability \\
\hline & & Share of green jobs \\
\hline Power and heat & $\mathrm{CO}_{2}$ per $\mathrm{kWh}$ generated $\left(\mathrm{g} \mathrm{CO}_{2 \mathrm{e}} / \mathrm{kWh}\right)$ & Thermal power plant efficiency $(\mathrm{kJ} / \mathrm{kWh})$ \\
\hline Industrial & Final energy use per unit industrial value added & $\begin{array}{l}\text { Physical efficiency (energy per ton of product) in } \\
\text { industrial subsectors, for example, iron and steel, } \\
\text { cement, aluminum, and ammonia }\end{array}$ \\
\hline \multirow[t]{3}{*}{$\begin{array}{l}\text { Commercial } \\
\text { Public }\end{array}$} & Final energy use per floor area or per employee & $\begin{array}{l}\text { Green buildings or LEED buildings or other } \\
\text { certification }\left(\mathrm{m}^{2} / \text { total }^{2}\right)\end{array}$ \\
\hline & Compliance with building efficiency codes (\%) & $\begin{array}{l}\text { Installed capacity of integrated renewable or CHP in } \\
\text { buildings }\left(\mathrm{W} / \mathrm{m}^{2}\right)\end{array}$ \\
\hline & & Space heating intensity $\left(\mathrm{MJ} / \mathrm{m}^{2}-\mathrm{HDD}\right)$ \\
\hline \multirow[t]{2}{*}{ Residential } & Final energy use per floor area or per capita & $\begin{array}{l}\text { Green buildings or LEED buildings or other } \\
\text { certification }\left(\mathrm{m}^{2} / \text { total } \mathrm{m}^{2}\right)\end{array}$ \\
\hline & Compliance with building efficiency codes (\%) & Space heating intensity $\left(\mathrm{MJ} / \mathrm{m}^{2}-\mathrm{HDD}\right)$ \\
\hline \multirow[t]{3}{*}{ Transportation } & Final energy use per capita & $\begin{array}{l}\text { Passenger energy or } \mathrm{CO}_{2} \text { per person- } \mathrm{km}(\mathrm{MJ} / \mathrm{p}-\mathrm{km} \text { or } \\
\left.\text { ton } \mathrm{CO}_{2} / \mathrm{p}-\mathrm{km}\right)\end{array}$ \\
\hline & $\begin{array}{l}\text { Public transit use (number of public transit trips per } \\
\text { capita) }\end{array}$ & $\begin{array}{l}\text { Freight final energy/ton-kilometer traveled }(\mathrm{MJ} / \mathrm{t}-\mathrm{km} \\
\left.\text { or ton } \mathrm{CO}_{2} / \mathrm{t}-\mathrm{km}\right)\end{array}$ \\
\hline & $\begin{array}{l}\text { Kilometers of public transit per } 100,000 \text { population } \\
(\mathrm{km} / \text { capita) }\end{array}$ & $\begin{array}{l}\text { Share of alternative fueled (hybrid, CNG, EV, and NG) } \\
\text { vehicles of the total vehicle fleet }(\%)\end{array}$ \\
\hline \multirow[t]{2}{*}{ Water and wastewater } & Energy intensity of water supply $\left(\mathrm{kJ} / \mathrm{m}^{3}\right)$ & $\mathrm{CO}_{2 \mathrm{e}}$ per volume of water supplied or treated \\
\hline & Energy intensity of wastewater treatment & \\
\hline \multirow[t]{2}{*}{ Waste management } & Volume of waste disposed (landfill) per capita & Recycling rate $(\%)$ \\
\hline & & Composting per capita (t/capita) \\
\hline \multirow[t]{2}{*}{$\begin{array}{l}\text { Agriculture and land } \\
\text { use }\end{array}$} & Urban green space per capita & $\begin{array}{l}\text { Area share of mixed-use zoning (residential and } \\
\text { commercial) }(\%)\end{array}$ \\
\hline & $\begin{array}{l}\text { Area share of urban forest cover, green space, and } \\
\text { agricultural land (\%) }\end{array}$ & \\
\hline
\end{tabular}

Source: Created by the authors using data from Zhou et al., 2011; World Bank, 2010, 2012.

transportation metrics on the life-cycle energy per personkilometer traveled (or vehicle mile traveled) show that public transit can use nearly six times less energy per passenger kilometer than private vehicles (Chester and Horvath, 2010; SF MTA, 2011). This life-cycle transportation metric highlights that nonmotorized and public transit modes are inherently lower-carbon than private vehicles, indicating that policies to promote a low carbon transportation mode balance are essential. Policies to improve private vehicle energy efficiency and utilize alternative fuels can help but are not sufficient. Electric cars alone cannot make a city's transportation sector low carbon, just as internal combustion engine vehicles alone did not solve the congestion problems of London's streets from the days of horse-drawn carriages (Jacobs, 1993).

Metrics and indicators can be used for analyzing historical trends, and as input to model future scenarios. Low carbon metrics can also be used to benchmark city performance over time, or in comparison with other cities. All of the uses of indicators and metrics can inform target setting, policy design, and monitoring policy implementation over time.

\section{STEPS IN LOW CARBON DEVELOPMENT}

\subsection{Climate action and low carbon development}

Low carbon development for cities is an intersection of citylevel climate action with urban planning, economic development, and other environmental and social priorities. The emphasis is typically on reducing GHG emissions (climate change mitigation). The Cities for Climate Protection (CCP) campaign by ICLEI-Local Governments for Sustainability has been a pioneering effort to exchange experience and 
promote climate action at the local level, including development of guidance materials and software tools. ${ }^{3}$ City climate actions plans (CAPs) initially focused on reducing GHG emissions and enhancing carbon sinks, that is, mitigation, such as the City of San Francisco Climate Action Plan (2006).

In addition, cities are often at the forefront of experiencing the impacts of climate change-including severe storms, flood events, heat waves, and drought-which in turn disrupt electric power supply, damage transportation and sewer infrastructure, exacerbate air pollution, and harm public health. Thus, cities have a direct motivation to incorporate climate change mitigation and adaptation into their infrastructure decisions and city planning. Over time, climate action planning is incorporating vulnerability assessments and resiliency planning for impacts already occurring and anticipated, that is, adaptation. The 2013 update to New York City's PlaNYC, "A Stronger, More Resilient New York," is one example.

The integration of climate action with economic development is still evolving, as economies face the postindustrial, postfossil fuel age. From Amsterdam to Austin, from Transition Townes to rust-belt revival towns, planning methods are being developed and cities are in the early stages of embarking on climate-friendly restructuring. This section focuses on the key steps for integrating energy and carbon savings into city planning and economic activity and closes with an example of the steps taken by the city of Chicago.

\subsection{Key steps}

Figure 1 summarizes the key steps utilized in low carbon development planning and implementation. These steps are taken in an iterative process, with ongoing monitoring informing updates in targets and policy implementation. While following the steps taken in order can inform city efforts in a systematic way, it is not uncommon for a city to first implement pilot strategies and then circle around to conduct a comprehensive GHG inventory and set formal targets. The most important step is to take a step.

\subsubsection{Commit leadership}

Because low carbon development permeates all aspects of city functioning, it is crucial to have committed leadership at the top, a champion who can leverage resources and spur coordination among the many participants needed. Urban sustainability leadership since the 1970s by Jaime Lerner, ${ }^{4}$ former mayor of Curitiba, Brazil and leadership by former New York City mayor Michael Bloomberg on PlaNYC (Chavez, 2010) are two examples of such committed leadership.

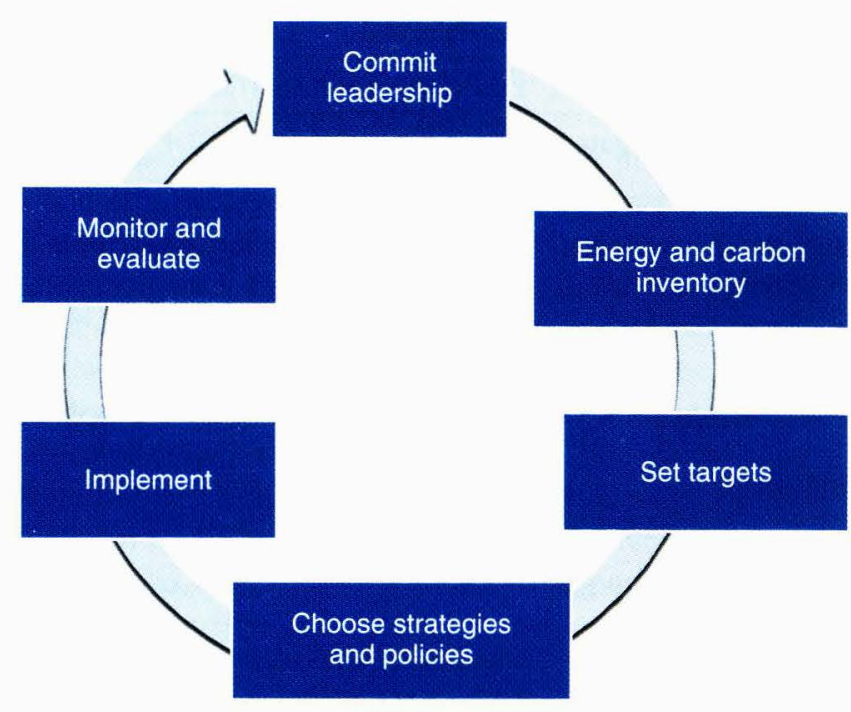

Figure 1. Steps in low carbon development. Source: Reproduced from Zhou et al., 2012. (C) Lawrence Berkeley National Laboratory and US Government.

Leadership is not a solo endeavor, however. Formation of a strong leadership team, a team that incorporates active public participation, is essential for low carbon economic development. Elements of the team include (Moffatt, Suzuki, and Izuka, 2012)

1. Champion: mayor or other community leader with strong credibility;

2. Change agent(s): manager(s) who work strategically and interact daily with members of the team, to see initiatives through start to finish;

3. Dedicated staff: staff across pertinent city government offices, with skills ranging from analysis and financing to communications and event planning;

4. Community support group: representatives of citizen groups, NGOs, developers, businesses, and coordinating government offices, who can provide insight and accountability and drive implementation of the initiatives;

5. Knowledge partner: a research institution or university that can provide independent, long-term analysis and facilitate knowledge exchange with other local, state, and international institutions.

\subsubsection{Energy and carbon inventory}

An energy and carbon inventory first serves to quantify the main sources of energy consumption and carbon-based GHG emissions of the city. A typical city inventory documents energy consumption and other activities that generate GHG emissions in the following sectors: electric power, 
industry, residential buildings, commercial and public buildings, transportation, land management (urban green spaces, agriculture and other land use), water, and waste.

The inventory then utilizes emission factors to estimate $\mathrm{CO}_{2}, \mathrm{CH}_{4}$, and other $\mathrm{GHG}$ emissions. City inventories may also distinguish between government-controlled operations and community (privately managed) operations (ICLEI USA, 2008). Details on inventory methods, data needs, the scope and sectors covered by an inventory, and comparative analysis of city inventories are discussed in Section 4.

\subsubsection{Set targets}

Targets for low carbon development can be overarching goals, such as reducing city-wide GHG emissions by $20 \%$ from the year 2000 to 2020 . Sector-specific targets support achievement of the city-wide goal and can be set for multiple low carbon indicators (as noted in Table 1), such as saving energy per unit of floor area or reaching a $75 \%$ diversion rate of solid waste to recycling and composting.

Setting the value of the targets can be done by benchmarking the city's existing performance for multiple indicators against performance over time or elsewhere and identifying potential levels of improvement. To see what level of overall carbon savings could result from these potential improvements, cities can forecast energy, GDP, and other indicators under different scenarios (business-as-usual, savings scenarios). Conversely, cities can back-cast from a scientifically advisable or socially desirable overall target to estimate the improvements needed in each sector.

The depth of analysis in target setting depends on the time and resources available. If time is limited, quick and rough scenario forecasts can be used to set targets. If more time is available, targets can be set based on detailed analysis of potential savings from particular policies and measures (the next step in low carbon planning). More details are provided in Section 5.

\subsubsection{Choose policy measures}

Multiple criteria inform the choice of policy measures, including the magnitude of carbon savings, the economic costs or savings, personnel capabilities, speed of implementation, and willingness of stakeholders. A rough screening analysis of potential policies, with qualitative or order-of-magnitude estimates, can identify a shorter list of policies for more detailed, quantitative analysis. Each policy should have a clear goal and a specific connection to a carbon saving target. For example, a city with a high share of transportation GHG emissions may have multiple targets and policy measures within the sector, such as improving the efficiency of the taxi fleet and enhancing the share of trips made by bicycle or public transit. Economic analysis of the policy measures can help identify the more costeffective measures for achieving carbon savings. Involving stakeholders in the selection and design of policy measures can garner better support for implementation. More details and specific examples are provided in Section 6.

\subsubsection{Implement}

Setting a target and choosing low carbon policies are only the beginning. The harder work comes with implementation. Active engagement among stakeholders is crucial. Engagement mechanisms are needed, including positive communication, training and guidance materials, targeted publicity, easing administrative burdens (e.g., permitting and reporting), and facilitation of financing. Initial success with pilot projects or catalyst projects can help garner funding and ease implementation. For example, the Sustainable Infrastructure Finance Network launched through C40 has the aim of sharing successes and challenges with financing to implement energy and carbon saving strategies. London's Green Fund and Chicago's Infrastructure Trust show by example how to leverage public and private investment (Carbon Disclosure Project, CDP, 2013). As city experience shows how low carbon measures can save cities money, the implementation of low carbon measures garners more support.

\subsubsection{Monitor and evaluate}

Monitoring and evaluation are much-needed components of the long-term process of low carbon development. From Chicago to London, cities making progress in low carbon development have earmarked funding for monitoring and evaluation and for reporting progress and updating the plan. For example, Chicago issues annual progress reports noting achievements for each indicator, goal, and progress toward the overall city target (City of Chicago 2012). Cities participating in the $\mathrm{C} 40$ climate initiative and reporting as part of the CDP $(2012,2013)$ provide updates and insights on their monitoring efforts.

Methodologies such as that of the $\mathrm{eCO}_{2}$ Cities initiative emphasize change management, or adaptive management, informed by monitoring and evaluation (Moffatt, Suzuki, and Izuka, 2012). Management of low carbon urban technologies such as Bus Rapid Transit (BRT) in Curitiba, Brazil is a powerful example of adaptive management. Frequent evaluation by city planners and exchange of information among stakeholders-bus drivers and passengers, researchers, and city officials-enabled improvements in the BRT system and further achievements in ridership and cost performance of the system (A Convenient Truth: Urban Solutions from 
Curitiba, 2007). Because the pursuit of low carbon cities is a new endeavor, adaptive management is a well-suited approach.

\subsection{City example: Chicago's steps}

Table 2 illustrates how all of the above-mentioned steps come together in an iterative process for low carbon development, with the city of Chicago as an example. Years before the city conducted a carbon inventory, Mayor Daley launched initiatives with multiple environmental and economic benefits, pointing the city toward low carbon development. Subsequently, Chicago set strong carbon targets supported with specific measures and monitoring, highlighted later.

\section{ENERGY AND CARBON INVENTORY METHODS}

An inventory of energy end-use, along with an inventory of other GHG-generating activities (water, waste, and land use), serves as the basis for a city's carbon inventory. These activity and emissions inventories in turn serve as the basis for developing an action plan to conserve energy, decarbonize energy supply, and alter other GHG-generating activities.

Cities face an interesting challenge of boundary setting as they track their GHG emissions and characterize the sources that generate those emissions. Cities straddle that mid-range spatial scale between facility and nation. Some large metropolitan areas are microcosms of national patterns

Table 2. Steps in low carbon development: the Chicago example.

\begin{tabular}{|c|c|}
\hline Step & Chicago Example \\
\hline Leadership & $\begin{array}{l}\text { Mayor Richard Daley shows early climate leadership, launching tree planting campaigns in 1989, } 1991 \\
\text { Landscape Ordinance requiring green elements in city development projects, } 1992 \text { Bike Plan, } 1995 \text { Greencorps } \\
\text { green jobs program } \\
\text { Leadership Team established with the Chicago Climate Task Force, including Research Advisory, Finance, and } \\
\text { Communications committees }\end{array}$ \\
\hline Inventory & $\begin{array}{l}\text { Chicago's emissions inventory highlighted that electricity use in the buildings sector ( } 43.5 \%) \text {, space and water } \\
\text { heating in the building sector }(27.8 \%) \text {, and on-road transportation }(20.2 \%) \text { are the dominant emission sources } \\
\text { Energy and GHG emissions are tracked annually }\end{array}$ \\
\hline Targets & $\begin{array}{l}\text { Chicago used detailed analysis and three main criteria to set targets that are } \\
\text { 1. sufficient to avoid an adversely altered climate, as agreed by scientists } \\
\text { 2. advantageous for Chicago by improving the quality of life and boosting the economy and } \\
\text { 3. feasible given current technologies and resources } \\
\text { Two overarching targets: } \\
25 \% \text { reduction of GHG emissions from } 1990 \text { to } 2020 \text { and } \\
80 \% \text { reduction of GHG emissions from } 1990 \text { to } 2050\end{array}$ \\
\hline Strategies & $\begin{array}{l}\text { Chicago chose strategies in five main areas, plus active engagement of the community: } \\
\text { 1. Energy-efficient buildings } \\
\text { 2. Clean and renewable energy sources } \\
\text { 3. Improved transportation options } \\
\text { 4. Reduced waste and industrial pollution } \\
\text { 5. Adaptation }\end{array}$ \\
\hline Implement & $\begin{array}{l}\text { Partnerships formed for each policy measure, for example, Energy Action Network of City of Chicago, Cook } \\
\text { County economic development association, utilities and energy service providers, and } 21 \text { community } \\
\text { organizations } \\
\text { Government leadership: } \\
\text { Public Building Commission energy efficiency improvements (fan systems and induction pumps) and } \\
\text { water-energy savings (low flow aerators, showers, and urinals) } \\
\text { Chicago Area Alternative Fuels Deployment Project (electric and biodiesel) } \\
\text { Chicago Parks District incorporating } 25 \% \text { renewable power }\end{array}$ \\
\hline Monitor and evaluate & $\begin{array}{l}\text { Evaluation of the Climate Action Plan found progress in the first } 2 \text { years: } \\
456 \text { measures developed by } 16 \text { City Departments and related agencies } \\
13,341 \text { housing units retrofitted to be more energy efficient } \\
393 \text { commercial and industrial buildings retrofitted to be more energy efficient } \\
20 \text { million more Chicago Transit Authority rides annually } \\
35 \text { million gallons of water conserved per day } \\
1.8 \text { million square feet of additional green roofs installed or under construction }\end{array}$ \\
\hline
\end{tabular}

Source: Created by the authors using data from Chicago Climate Action Plan (City of Chicago, 2008); Chicago 2010 Regional Greenhouse Gas Emissions Inventory (ICF International, 2010); and Chicago Climate Action Plan--Progress Report 2008-2009 (City of Chicago, 2010). 
Table 3. City-level GHG emissions inventory methodologies.

\begin{tabular}{|c|c|}
\hline GHG Inventory Methodology Utilized by Cities & Organizations and Timing \\
\hline Guidelines for National Greenhouse Gas Inventories & Intergovernmental Panel on Climate Change (IPCC) $(1996,2006)$ \\
\hline GHG Protocol-Corporate Standard & $\begin{array}{l}\text { World Resources Institute (WRI) and World Business Council for Sustainable } \\
\text { Development (WBCSD) (WRI and WBCSD, 2004) }\end{array}$ \\
\hline $\begin{array}{l}\text { Bilan Carbone-Methodological Guide for Compa- } \\
\text { nies and Local Authorities }\end{array}$ & Agence de l'Environment et de la Maitrice de l'Energie (ADEME, 2007) \\
\hline $\begin{array}{l}\text { Greenhouse Gas Regional Inventory Protocol } \\
\text { (GRIP) }\end{array}$ & $\begin{array}{l}\text { Tyndal Centre for Climate Change Research, University of Manchester, UK } \\
\text { Environmental Agency (GRIP, 2008) }\end{array}$ \\
\hline $\begin{array}{l}\text { International Local Government GHG Emissions } \\
\text { Analysis Protocol (v.1.0) }\end{array}$ & $\begin{array}{l}\text { International Council for Local Environmental Initiatives (ICLEI)-Local } \\
\text { Governments for Sustainability (ICLEI 2009) }\end{array}$ \\
\hline $\begin{array}{l}\text { Inventory of US Greenhouse Gas Emissions and } \\
\text { Sinks: } 1990-2007\end{array}$ & US Environmental Protection Agency (US EPA, 2009) \\
\hline $\begin{array}{l}\text { Baseline Emissions Inventory/Monitoring Emis- } \\
\text { sions Inventory Methodology }\end{array}$ & European Commission-Covenant of Mayors (2009) \\
\hline Local Government Operations Protocol (LGOP) & $\begin{array}{l}\text { ICLEI-USA, California Climate Action Registry (CCAR, 2009), California Air } \\
\text { Resources Board (CARB 2010) }\end{array}$ \\
\hline $\begin{array}{l}\text { International Standard for Determining Greenhouse } \\
\text { Gas Emissions for Cities }\end{array}$ & $\begin{array}{l}\text { United Nations Environment Program (UNEP), United Nations Human } \\
\text { Settlements Program (UN Habitat), and the World Bank (UNEP et al., 2010) }\end{array}$ \\
\hline $\begin{array}{l}\text { Local Government-Developing a Greenhouse Gas } \\
\text { Inventory }\end{array}$ & US Environmental Protection Agency (US EPA, 2013b) \\
\hline $\begin{array}{l}\text { Global Protocol For Community-Scale Greenhouse } \\
\text { Gas Emissions (GPC) (Pilot v.1.0) }\end{array}$ & $\begin{array}{l}\text { C40 Cities Climate Leadership Group and ICLEI, in collaboration with World } \\
\text { Resources Institute, World Bank, UNEP, and UN-HABITAT (WRI et al., } \\
\text { 2013) }\end{array}$ \\
\hline
\end{tabular}

of energy consumption and carbon emissions. Other cities have pushed carbon-intensive activity outside of their boundaries and consume the goods and foods produced elsewhere. With their subnational scale, cities may have more permeable boundaries. Compared to individual facilities or corporations, cities have a wider range of emission sources. As mid-size hubs of human activity, cities may find it more challenging to attribute carbon emissions to activities within the city versus those occurring outside city boundaries yet still driven by the activities of the city. Nonetheless, at this mid-size scale, cities are well positioned to initiate local energy and carbon saving actions that can have a large influence nationally and globally.

\subsection{Development of inventory methods}

Methodologies for city-level GHG inventories have evolved a great deal over the past decade. Development of nationaland facility-level inventory methods preceded those of cities. Methodology from the IPCC for national-level GHG reporting (IPCC, 1996, 2006), and the now widely accepted GHG Protocol for corporate (facility level) emissions inventories (World Resources Institute, WRI and World Business Council for Sustainable Development, WBCSD, 2004), along with several other initiatives, have informed city inventories. Ibrahim et al. (2012) and World Bank (2012) offer helpful comparisons of inventory methods. Organizations are now teaming up to develop standardized methodologies. Table 3 lists many of the key initiatives in development of city-level GHG emissions inventory methodology.

\subsection{Scope and sectors}

An emissions inventory is a best estimate of emissions from activities in the city-not a precise measurement. The two main carbon-based emissions tracked by the inventory are $\mathrm{CO}_{2}$ and $\mathrm{CH}_{4}$. Emissions of $\mathrm{CO}_{2}$ are primarily from energy consumption of fossil fuels, as well as from nonenergy industrial processes (e.g., cement production), and forest loss. $\mathrm{CH}_{4}$ arises from agriculture (especially rice production), animal husbandry, other land use, industry (e.g., coal-bed $\mathrm{CH}_{4}$ ), and waste decomposition.

As some emission-generating activities may cross city boundaries, it is important to clearly define the scope of the emissions inventory, to know what emissions get counted by the city. Internationally recognized inventory protocols have defined three emission scopes: (i) direct, (ii) indirect, and (iii) associated emissions. See Table 4 for the activities generating GHG emissions in each scope. 
Table 4. Energy and carbon inventory: GHG emissions scope.

\begin{tabular}{|c|c|}
\hline Emissions Scope & Scope Activities \\
\hline $\begin{array}{l}\text { Scope 1. Direct emissions } \\
\text { Generated within city bound- } \\
\text { aries }\end{array}$ & $\begin{array}{l}\text { Direct energy consumption } \\
\text { within the city (fuel for } \\
\text { industry, heating, cooling, } \\
\text { electricity generation, } \\
\text { infrastructure, etc.) } \\
\text { Transportation within the city } \\
\text { Land use and waste } \\
\text { management within the city }\end{array}$ \\
\hline $\begin{array}{l}\text { Scope } 2 \text {. Indirect emissions } \\
\text { Owing to activities within city } \\
\text { boundaries, generated outside } \\
\text { city boundaries }\end{array}$ & $\begin{array}{l}\text { Import of electricity and heating } \\
\text { used in the city }\end{array}$ \\
\hline
\end{tabular}

Scope 3. Associated emissions Intraregional transportation

Owing to city activities occur- City waste in landfills outside ring across or outside city the city

boundaries

Source: Created by the authors using data from ICLEI, 2009; US EPA, 2013b; Local Government GHG Inventory; WRI-WBCSD GHG Protocol; IPCC Reporting Guidelines for GHG Emissions.

\subsection{Data needs}

Because low carbon development permeates all aspects of the city, data-gathering for the energy and carbon inventory involves multiple government offices and organizations. Table 5 summarizes the emissions sources and basic data needs for an inventory, citywide and for particular sectors.
Energy data distinguished by fuel (natural gas, diesel, gasoline, coal, etc.) or energy source (electricity, wind, solar, etc.), along with activity data (e.g., industrial production levels, vehicle miles traveled, and recycling rates), are necessary to determine GHG emissions. The breakdown in energy data is also needed to analyze patterns of energy demand and identify potential areas for energy and carbon savings. The sectors could be further disaggregated if more detailed data are available. For example, the commercial buildings sector could be disaggregated by building type, from retail to hospitals and data centers. Industry could be detailed by subsector or process, such as cement and semiconductors.

Energy and economic inventory. Starting with an energy inventory of the city helps identify not only greenhouse emissions but also opportunities for economic savings. Collecting economic data along with energy and carbon data further integrates the economic development aspect of low carbon development. Economic data may relate to aspects of government operation and infrastructure or to aspects of city economic policies that could promote low carbon alternatives. For example, Cleveland, Ohio conducted an energy audit and sustainability assessment of key city infrastructure, including public buildings and water and waste treatment facilities. The audit identified an energyintensive dehumidification unit in the water treatment plant that could be shut down without adverse effects. Shutting down the unit saved energy, carbon, and US $\$ 160,000$ over a 2-year period. The Cleveland recycling program diverted $\mathrm{CH}_{4}$-generating waste and energy-intensive materials from landfill and saved nearly US\$1 million over the same 2-year period (ICLEI, 2010). More examples are noted in Section 6.

Table 5. Basic data needs for a city energy and carbon inventory.

\begin{tabular}{ll}
\hline Sector (Emissions Source) & Data (Annual, for Multiple Years) \\
\hline City-wide & Population, city area, climate zone, and GDP (total and sectoral shares) \\
Electric power & Energy mix of generation: kWh from coal, natural gas, oil, hydro, wind, solar, nuclear, etc. \\
Industrial & Electricity and fuel (natural gas, coal, heat, and others) consumption \\
Residential buildings & Electricity and fuel (natural gas, coal, heat, and others) consumption \\
& Building floor space and type \\
Commercial buildings & Electricity and fuel (natural gas, coal, heat, and others) consumption \\
& Building floor area and type \\
Transportation & Electricity and fuel (gasoline, diesel, and others) consumption \\
& Transport modal mix and fleet efficiencies (feet, bicycle, motorbike, bus, light rail, train, auto, and truck) \\
& Vehicle miles traveled (VMT) on local roads, for each mode \\
& VMT on highways (related to the jurisdiction) for each mode \\
Water and wastewater & Electricity and fuel (natural gas, coal, heat, and others) consumption \\
& Volume of water and wastewater processed \\
Land use & Hectares of food production (rice and other) \\
& Numbers of cattle, pigs, and horses \\
Waste & Hectares of forest cover and green space (existing, removed, added) \\
& Total landfill waste (tons) \\
& Typical composition of waste (organic matter, plastics and other nondegradable material, and land-cover \\
materials) & Waste diversion (tons) with reuse, recycling, and composting \\
\hline
\end{tabular}

Source: Reproduced from Zhou et al., 2011. (C) Lawrence Berkeley National Laboratory and US Government. 
Infrastructure inventory. Finally, including an inventory of a city's natural and infrastructure assets, and institutional capabilities, along with energy and carbon, enables assessment of the city's resiliency to climate change impacts. Investments in a subway system for low carbon transport would not pay off if the infrastructure is not designed to handle flooding from climate-change-induced storm surges. Much work is still needed to incorporate infrastructure inventories and vulnerability assessment into low carbon development; city analysis that incorporates both elements includes World Bank (2010) and CDP for Cities (2011, 2012, 2013).

\subsection{City inventories for low carbon development}

While other analyses have compared inventory methodologies across cities to help refine the methodologies (cf. Ibrahim et al., 2012), in the context of low carbon development, we are interested in the insight a carbon inventory offers for action. Here, we examine the carbon inventories of three cities: Paris (Ile de France), Los Angeles, and New York City (Figures 2-4, respectively). Each of these inventories utilizes a slightly different organization and representation of emission generating activities. The Los Angeles inventory presents energy and emission sources (e.g., electricity and direct fuel consumption in buildings), whereas the Paris and New York City inventories attribute electricity and other emissions to the end-use sectors, including residential buildings, commercial buildings, industry, transportation, and solid waste. The more detailed the activity data on energy end-use and resource use, the better the insight offered for energy and carbon savings, as well as economic opportunity.

The Paris inventory shown in Figure 2 is based on the Greenhouse Regional Inventory Protocol (GRIP) methodology from the United Kingdom and the EU (GRIP, 2009).

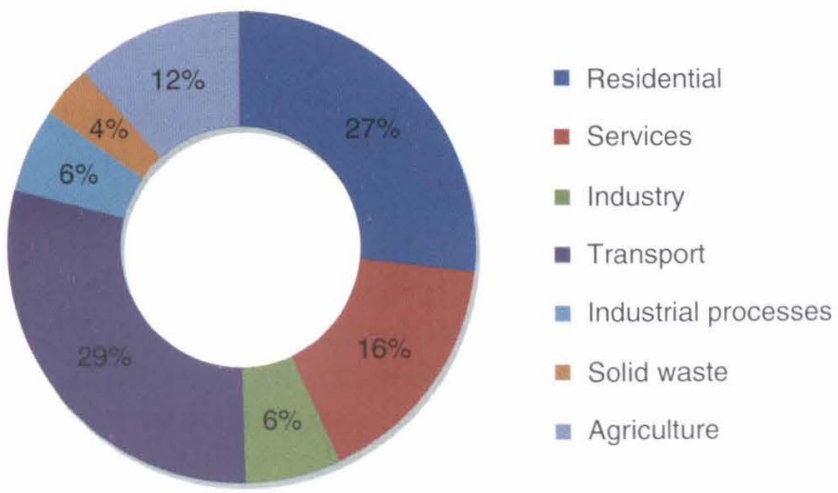

Figure 2. Paris (Ile de France) GHG Emissions Inventory (2005). Source: Created by the authors using data from GRIP, 2009.

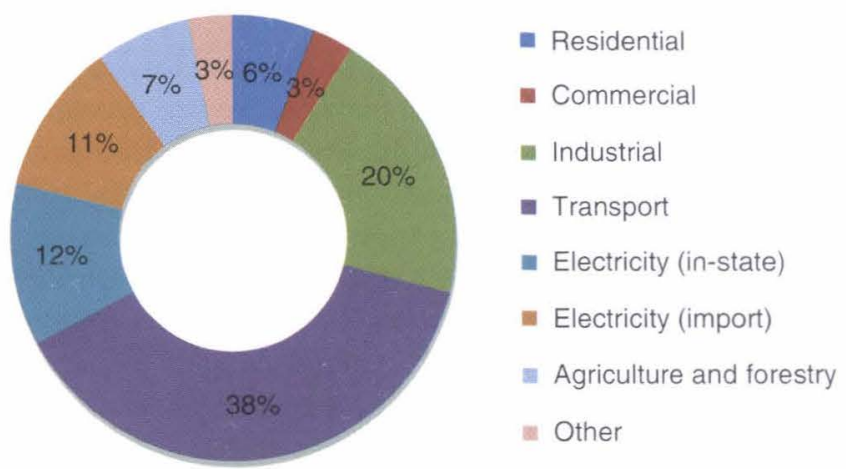

Figure 3. Los Angeles GHG Emissions Inventory (2009).
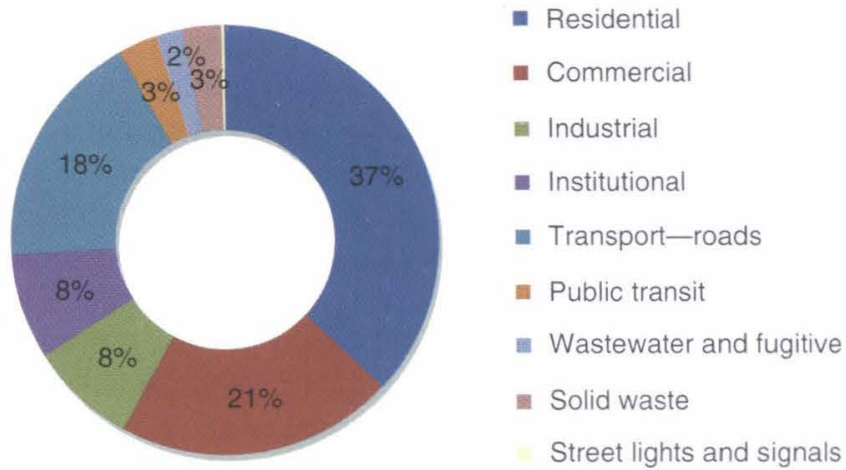

Figure 4. New York City GHG Emissions Inventory (2010).

In the Parisian climate action plan (City of Paris, 2007), the city utilized the Bilan Carbone method, developed with the French energy agency, ADEME (2007). The Paris GRIP inventory shows the largest shares of GHG emissions from building sectors (residential $27 \%$ and services $16 \%$ ) and transportation (29\%). In Figure 2, we cannot see the breakout of emissions from on-road passenger transportation compared to public transit (rail and subway) and freight, whereas the Paris Climate Plan presents greater detail. Two types of emissions are shown for the industrial sector: energy-related emissions in industry and process-related emissions (SF6) in industrial processes, together accounting for $12 \%$ of GHG emissions in the greater metropolitan area of Paris. Solid waste yields $4 \%$ of urban emissions, whereas the agricultural areas surrounding the city center contribute $12 \%$ of emissions.

In comparison, the more sprawling city of Los Angeles has a $38 \%$ share of GHG emissions in the transportation sector (see Figure 3), nine percentage points higher than Paris. Rather than attribute emissions from electricity generation to end users, the Los Angeles inventory calls out the power 
sector: $12 \%$ from in-state generation and $11 \%$ from outof-state generation. This framing of the inventory is done, in part, to connect goals for renewable power generation to the electric utilities responsible for meeting those goals. However, emissions due to activity in the residential $(6 \%)$ and commercial (3\%) sectors appear smaller than they actually are, as those building sectors do not include electricityrelated emissions under this inventory method. The relatively small share of the Los Angeles residential and commercial sectors is also due to regional climate-the mild southern California coastal climate does not have the heating demands of the more northern and in-land French capital city. The industrial sector of Los Angeles is sizeable at 20\%, the result of oil refining, aerospace, and other industry in the area.

As "the city that never sleeps," New York City has an unsurprisingly high share of $37 \%$ GHG emissions from the residential sector (see Figure 4). With a population density on par with Paris (World Bank, 2010), New York City's residential sector claims the largest inventory share of the three city inventories examined above. The commercial sector follows at $21 \%$, and institutional (government or public) buildings are noted as a distinct sector with an $8 \%$ share of emissions. The industrial sector for New York City comes in at $8 \%$, compared to Paris at $6 \%$ and Los Angeles at 20\%. A distinction is made in the transport sector between roads $(18 \%)$ and public transit (3\%), highlighting the low carbon efficacy of multipassenger modes of transport. Along with the high population density comes a waste management challenge, $2 \%$ of emissions from wastewater and fugitive sources and $3 \%$ from solid waste.

In the rest of this chapter, we examine how metrics and the energy and carbon inventory inform target setting and policy measures for low carbon development.

\section{LOW CARBON TARGETS}

\subsection{Types of targets}

City targets for low carbon development can be set as overall energy and carbon targets and for any of the low carbon metrics identified at the beginning of this chapter. The choice of metric can be just as important as the value of the target for spurring action. Targets need to be reportable and measurable, so that progress can be tracked. Physical targets, such as absolute $\mathrm{CO}_{2}$ emissions, energy use, or kilowatt-hours of wind energy, are powerful because they can be measured quantitatively and have a direct influence on the health of the city.

Intensity targets, such as energy consumed per unit of product or $\mathrm{CO}_{2}$ emitted per unit of economic output, encourage efficiency in city activities along with carbon saving. The advantages of intensity targets are that they measure energy or GHG trends independent of production growth or decline and recalculation of target or base year goals is not needed if there are changes in product mix or production volume. In addition, such targets can allow comparison of enterprise performance with other enterprises that produce similar products or with best practice. The disadvantages are that as the target is independent of production growth, the level of actual GHG emissions in the target year is not set and therefore could be higher than the base year, depending on production trends (WBCSD/WRI, 2004).

Qualitative targets have their role. Acknowledging the establishment of a low carbon working group, or the issuance of progress reports, keeps attention on the city's efforts and motivates participation. Economic targets are important too; the goal is to have a thriving economy that is low carbon and sustains well-being.

\subsection{Target setting}

Once the type of overall target is decided-absolute energy or carbon savings or improvement in carbon intensity of the economy-the next step is to set the value of the target. For example, Tokyo has pledged to reduce overall city GHG emission 25\% from the year 2000 to 2020, while New York set a $30 \%$ reduction target from 2005 to 2030 (CDP, 2012). The city of Tianjin is targeting carbon intensity of the economy. By 2015, the goal is a carbon intensity of 1.69 ton/10,000 RMB, $15.5 \%$ less than that of 2010, which had the target of $2.00 \mathrm{ton} / 10,000 \mathrm{RMB}$ (Wang, 2011). The target value is typically set by making forecasts of energy and carbon under different scenarios, based on city planning, anticipated population change, and potential energy and carbon savings. At least two scenarios are examined: business-as-usual scenario, and savings (reduction) scenario. For Chinese cities, the carbon intensity targets are predominantly set by allocation of national and provincial targets down to the cities.

\subsection{City example: Portland's low carbon targets and sectoral goals}

By specifying sectoral goals for carbon saving, cities can strengthen the connection with city-wide targets. Interim goals help place a city on a path to achievement of long-term carbon saving targets. Table 6 illustrates the connection between city-wide targets and sectoral goals in the climate action plan from the city (and surrounding county) of Portland, Oregon. Portland's long-term target $-80 \%$ reduction 
Table 6. Connecting city targets and sectoral low carbon goals: Portland, Oregon.

Overall City Target: Reduce $\mathrm{CO}_{2 \mathrm{e}}$ Emissions by $40 \%$ between 1990 and 2030

Long-Term Target: Reduce $\mathrm{CO}_{2 \mathrm{e}}$ Emissions by $80 \%$ between 1990 and 2050

\section{Sector 1. Buildings and Energy}

Goal 1. Reduce the total energy use of all buildings built before 2010 by $25 \%$

Goal 2. Achieve zero net greenhouse gas emissions in all new buildings and homes

Goal 3. Produce $10 \%$ of the total energy used within Multnomah County from on-site renewable sources and clean district energy systems

Goal 4. Ensure that new buildings and major remodels can adapt to the changing climate

Sector 2. Urban Form and Mobility (Transportation)

Goal 5. Create vibrant neighborhoods where $90 \%$ of Portland residents and $80 \%$ of Multnomah County residents can easily

walk or bicycle to meet all basic daily, nonwork needs and have safe pedestrian or bicycle access to transit

Goal 6. Reduce per capita daily vehicle-miles traveled (VMT) by $30 \%$ from 2008 levels

Goal 7. Improve the efficiency of freight movement within and through the Portland metropolitan area

Goal 8. Increase the average fuel efficiency of passenger vehicles to 40 miles per gallon and improve performance of the road system

Goal 9. Reduce the life-cycle greenhouse gas emissions of transportation fuels by $20 \%$

Sector 3. Consumption and Solid Waste

Goal 10. Reduce total solid waste generated by $25 \%$

Goal 11. Recover $90 \%$ of all waste generated

Goal 12. Reduce the greenhouse gas impacts of the waste collection system by $40 \%$

Sector 4. Urban Forestry and Natural Systems

Goal 13. Expand the urban forest canopy to cover one-third of Portland, and at least $50 \%$ of total stream and river length in the city meet urban water temperature goals as an indicator of watershed health

Sector 5. Food and Agriculture

Goal 14. Reduce consumption of carbon-intensive foods

Goal 15. Significantly increase the consumption of local food

Sector 6. Community Engagement (Public and Business)

Goal 16. Motivate all Multnomah County residents and businesses to change their behavior in ways that reduce carbon emissions

Sector 7. Climate Change Preparation

Goal 17. Adapt successfully to a changing climate

Sector 8. Local Government Operations

Goal 18. Reduce carbon emissions from city and county operations 50\% from 1990 levels

Source: Reproduced from Zhou et al., 2011. (C) Lawrence Berkeley National Laboratory and US Government.

from 1990 to 2050 - acknowledges the dramatic reductions in GHG emissions indicated by scientific consensus (IPCC, 2007). The overall city target of $40 \%$ reduction from 1990 to 2030 is still a rather long-term target; to work toward it, Portland's plan elaborates actions within a 10-year time-frame, in addition to the sectoral targets shown in Table 6.

Portland's choice of sectors and goals is in itself informative. By designating buildings and energy as one sector, Portland is emphasizing energy end-use strategies for low carbon development. Goal 1 for that sector is an energy conservation goal: reduce energy use $25 \%$ in existing buildings. After that lightening of energy demand, attention then turns to net-zero carbon for new buildings (Goal 2), supported by a strategy of distributed renewable energy supply (Goal 3 ).

The urban form and mobility sector emphasize the importance of urban design as a driving force for transportation mode choices and trip length. The foundational goal for the sector is to structure neighborhoods to allow easy access to most daily needs by foot or bicycle, significantly lessening the demand for motorized transportation (Goal 5 in
Table 6). Next in priority is reducing vehicle miles traveled (Goal 6), which can be accomplished by greater use of public transit, carpooling, telecommuting, and trip linking. Improving efficiency of freight transport and individual vehicles are subsequent goals, along with decarbonizing vehicle fuel. By emphasizing changes in the underlying urban patterns that influence mobility, not only incremental changes in vehicle technology but Portland has also set a path toward achieving its ambitious - yet necessary —overall target of $80 \%$ carbon savings by 2050 .

\section{POLICY MEASURES FOR CITY ENERGY AND CARBON SAVINGS}

Having identified methods for inventories of energy and GHG emissions, and examples of future scenarios and targets, we examine policy measures that are already being utilized by cities around the world to save carbon and energy and promote low carbon economic development. 
The measures cover the spectrum of policy types, from cross-cutting fiscal planning for long-term infrastructure investments to sector-specific technology standards to community dialog and charrettes for neighborhood enhancements that encourage nonmotorized transportation.

These policies may have as their focus one of the low carbon metrics introduced at the beginning of this chapter, such as the share of renewable energy in city electricity supply or the utilization rate of public transit. The city may lead by example, converting the city bus fleet to run on renewable fuels or mandating highly energy-efficient construction of public buildings. To raise awareness among the public and businesses, the city's low carbon plan may include energy efficiency labeling programs, information dissemination programs for low carbon construction and retrofit of buildings, and climate education programs in the city schools.

The selection and prioritization of policies is a challenging task for cities, because so much needs to be done to achieve dramatic carbon savings across city sectors, while nourishing a climate-friendly economy. Criteria for policy selection may include carbon saving potential, speed of implementation, first cost to government, city government jurisdiction, personnel capabilities needed, and political and social ease of implementation. Cities that are making progress in low carbon development typically have a mix of near-term showcase projects, coupled with long-term investments in infrastructure. For example, efficiency retrofits and photovoltaic installations in a public building offer an immediate and visible sign of carbon savings to the public, especially when followed by progress reports on energy and cost savings. Longer-term efforts for a BRT system, or shifting city power supply to $100 \%$ renewables, require early initiation and persistent shepherding through the many steps to actualization.

The following policy measures highlight low carbon development in four city sectors: urban form and transportation, buildings, industry, and energy supply. We draw upon city examples from China and the United States, Mexico and South Africa, Japan, and several countries across Europe.

\subsection{Urban form and transportation}

\subsubsection{Urban form with mixed-use zoning}

From the perspective of energy systems and urban planning, deep cuts in transportation sector energy and carbon require an urban design that places people close to their basic needs, alleviating the need for motorized transport. While many cities established before the age of the internal combustion engine intermingled essential services and businesses with residences, car-oriented cities will need to shift to an urban form with mixed-use zoning. A low carbon urban form has human-scale, mixed-use neighborhoods where the majority of residents can walk or bicycle to meet basic, nonwork, daily needs (Calthorpe, 2011). Keeping these needs within walking or bicycling distance dramatically reduces vehicle travel, energy use, and $\mathrm{CO}_{2}$ emissions (City of Portland, 2009). Rather than towering concrete buildings separated from daily needs of people, cities can gather together services, retail, recreation, and housing within walkable distances and pedestrian-friendly configurations. For residents who must go outside the neighborhood for their job, safe access to walking and bike paths and public transit is needed for the work commute. Residents and workers-and their employers and the businesses they interact with - benefit from clusters of daily destinations in mixed-use zoning.

\subsubsection{0-minute neighborhoods: Portland, Oregon}

An oft-cited example of a city that has chosen a peoplefocused urban form, despite American trends to the contrary, is Portland. With only $11 \%$ of the city designated as $20-$ minute neighborhoods thus far, Portland residents already drive $20 \%$ less than residents of similarly sized US cities. Not only does the mixed-use urban form save energy and carbon, it also saves money on transportation. Portland Mayor Samuel Adams estimates that Portland's residents are nearly $\$ 800$ million richer every year by driving less frequently (Maher, 2013). With more data and education, even more progress can be made. Federal agencies typically base funding on the amount of car travel, whereas the 20-minute neighborhood zoning emphasizes "the trips not taken," that is, avoided car travel. The city has turned to funds from other sources for necessary infrastructure investment, such as pathways to the local market and school, retro-fit of utilities to accommodate mixed-use commercial and residential facilities, or connecting a community center and nearby streets with bicycle lanes (Maher, 2013).

\subsubsection{Complete streets}

Complete streets, also called "multimodal streets," promote a holistic approach to urban transportation. Shifting away from an emphasis on private vehicle traffic, complete streets aim to balance multiple transport modes and create appealing urban spaces (Vance, 2013). Design features of complete streets include signage and lane striping, raised crosswalks and pedestrian control signals, bus pull-outs, and traffic calming measures (NYC DOT, 2012). Rather than huge multilane two-way intersections, pairings (couplets) of one-way streets can provide easier crossing for pedestrians while still facilitating traffic flow of vehicles (SF MTA, 2011). 
Even US cities dominated by streets for automobiles are making a shift in their transportation mode mix. The complete streets experience in Memphis, Tennessee (population 655,000) is pragmatic and publicly engaging. A campaign in 2010 to revitalize the Broad Avenue neighborhood led to 25 new businesses and a vibrant commercial area (Snyder, 2013). The sidewalk vendors, public street furniture, bike lanes, and street calming were so successful that they stayed beyond the campaign. This positive experience in street redesign led to the passing of a complete streets city policy. The incorporation of bike lanes, improved pedestrian features, and better transit access were done with very little budget, by making the changes when street resurfacing was already planned. With this approach, over 50 miles of bike lanes were installed within 2 years. The complete streets improvements also have an important health benefit by encouraging walking and bicycling, an essential public health measure for a population with $60 \%$ obesity (Snyder, 2013).

\subsubsection{Promoting vehicle fuel economy: city taxis}

In Mexico City, taxis account for $35 \%$ of vehicular transport (C40 Climate Initiative, 2010). To alleviate oil consumption and air pollution, as well as reduce GHG emissions, the municipal government set a requirement to replace taxis that are at least 8 years old with more efficient models. New taxis must have a fuel efficiency of at least $12.5 \mathrm{~km} / \mathrm{L}(29.4$ miles/gallon). The local government provides a subsidy of nearly US $\$ 1380$ per driver to buy a new taxi. To enable financing of the auto purchases, the municipal government formed a partnership with a local bank. The bank agrees to grant taxi drivers loans to pay off the typical remaining cost (approx. US\$4950), with a development bank acting as the guarantor of the loan. The government revokes the new car if the driver does not repay the loan within 4 years. The first round of the program had a capital cost of roughly US $\$ 4$ million (C40 Climate Initiative, 2010).

Cities in the United States are also focusing on the fuel economy of taxi fleets. Because taxis are high mileage vehicles, better fuel efficiency for taxis can achieve significant and immediate savings in energy and carbon. For example, taxis in New York City travel 80,000 miles per year, while a typical passenger car travels roughly 15,000 miles per year (New York City, Office of the Mayor, 2011). Utilizing fuelefficient taxis could reduce GHG by 296,000 tons, the equivalent of taking 35,000 cars off the road. At 2011 gas prices, drivers of efficient and/or hybrid taxis could save an average of US\$5250 in gas costs per year. These efforts enhance air quality and human health; improved taxi efficiency can reduce lung-damaging nitrogen oxide emissions by $71 \%$ and hydrocarbons by $89 \%$ (New York City, Office of the Mayor,
2011). This approach would also save on life-cycle energy and carbon in the fleet.

Other US cities are taking a similar approach. As part of the Minneapolis city climate action plan, the city requires that taxi vehicles licensed in the city achieve 23 miles per gallon $(9.8 \mathrm{~km} / \mathrm{L})$ or better in local driving. However, city plans for more efficient taxis are meeting with legal opposition in some locations. Opponents argue that city government does not have authority to call for stricter-than-national standards. Law-making efforts are underway at the state and national levels to enable this type of low carbon transportation policy measure.

\subsection{Buildings sector}

The urban buildings sector-including residential, commercial, and public buildings-typically accounts for one-quarter to one-half of city GHG emissions. (Refer to the city carbon inventories in Figures 2-4 for examples). Cities have the authority to push for significant energy and carbon savings in new construction, as well as gradually implementing retrofit of existing building stock. Complementary policies and financial incentives can contribute to effective implementation in the buildings sector, with policy measures including energy audits, city maps of energy consumption and renewable energy potential, building energy efficiency codes, expedited permitting, targets for green building and net-zero energy building, more stringent appliance efficiency standards, and tax breaks on investments in energy efficiency or building-scale renewable energy systems. Here, we highlight three policy measures that contribute to savings in residential buildings, as well as commercial and public buildings: building energy codes, net-zero and green building policies, and building workforce training programs.

\subsubsection{Building energy codes: from envelope and HVAC to design and operation}

Energy policies for the buildings sector highlight the importance of demand-side management of energy for low carbon development. Building energy codes are one of the most important policy measures for improving building energy efficiency levels because they set the minimum requirements (i.e., baseline) for energy-efficient design and construction. Building energy codes generally apply to both new buildings and major renovations and to both residential and commercial buildings. Although building energy codes are often developed at the national level as a model or baseline code, they are typically adopted and enforced by local governments. 
Energy codes for building envelope and HVAC. Traditionally, building energy codes dictate the energy efficiency of several building components:

- building envelope walls, floors, ceilings, doors, and windows;

- heating, ventilating, and cooling systems and equipment (HVAC);

- lighting systems and equipment; and

- water-heating systems and equipment.

Design code for operational energy saving. More recently, new building energy codes have started to introduce requirements beyond energy performance to promote low energy and low emissions buildings. These new requirements include design and operational measures that help reduce the need for energy services while maintaining the same comfort level (e.g., daylighting and cool roofs), integration of renewable energy sources and broader environmental requirements. In the United States, for example, most states in warm climate zones now include prescriptive requirements for cool roofs, which can reduce the air conditioning demand by up to $20 \%$ and reduce thermal heat transfer to the outdoor environment, in their building energy codes (IEA, 2013). In France, the 2012 building energy code added new requirements for designs that maximizes bioclimatic factors such as solar gain, shading, and daylight and the use of renewable energy sources including biomass and district heating where possible (IEA, 2013).

Building efficiency code in California. Adopting more stringent building code requirements has become a policy focus for regions and cities pursuing low carbon development because they can significantly and cost-effectively reduce the energy consumption of buildings, one of the largest energy end-users in the urban environment. In the United States, California's state-developed mandatory building energy code known as Title 24 is considered one of the most stringent and best enforced codes. The most recent Title 24 code adopted in 2013 requires 25\% energy reduction in lighting, heating, cooling, ventilation, and water heating for all new construction (CEC, 2013). Many towns and cities in California have-with the state's approval-adopted energy ordinances requiring even more stringent building efficiency requirements than Title 24 (CEC, 2014). The 2012 Santa Monica Municipal Code, for instance, requires all new construction and substantial retrofits to exceed California Title 24 requirements by $10 \%$. The city code also calls for the use of solar heating for pools, hot water pipe insulation, green building materials, and waste diversion (City of Santa Monica, 2014).

The City of Boulder, Colorado also adopted a local ordinance requiring that all commercial buildings must exceed the current model building energy code by $30 \%$ (US DOE,
2014). In China, the major cities of Beijing and Tianjin have adopted mandatory residential building energy codes that are more stringent than the national code. Some cities have integrated other sustainable and low carbon practices into their municipal code for buildings.

Besides directly adopting a more stringent local code, other regions have sought to increase the baseline efficiency level of specific building types through policies such as more stringent efficiency requirements for government-owned buildings. Several states in the United States, including New Hampshire, Oregon, and Montana, have adopted local legislation requiring that the new construction and retrofit of all state-owned buildings exceed the existing state energy code by $20 \%$ (US DOE, 2014). Setting more stringent energy efficiency requirements for state-owned buildings allows states to lead by example and demonstrate the feasibility and cost-effectiveness of constructing more efficient buildings.

\subsubsection{Net-zero and green buildings in low carbon cities}

As jurisdictions responsible for setting building codes and issuing building permits, cities hold the power to define and transform the urban environment. City governments may be the single largest owners of urban space and users of design and construction services in the locality (Athens, 2010). As such, cities and the building policies they adopt can shape the evolution of low carbon buildings that are not only energy efficient but also have decarbonized energy and a much smaller environmental footprint overall.

Low carbon buildings have become desirable policy goals for low carbon cities because they help achieve energy and carbon savings above and beyond those resulting from traditional mandatory building energy codes and voluntary building energy labels. More recently, policies at all levels of government have started to focus on promoting net-zero energy buildings with very high energy performance where the nearly zero or very low amount of energy required is met with renewable energy and green buildings with superior energy and environmental performance over the building's entire life-cycle. Because nearly all net-zero buildings require energy demand to be met with energy supplied by renewable resources, they also achieve significant reductions in energy-related $\mathrm{CO}_{2}$ emissions, possibly to the point of net-zero carbon. Similarly, green buildings are designed to consume less energy, water, and materials and emit lower emissions over the building's decades-long lifetime.

Policies that have been adopted to support the development of low carbon buildings have included setting targets for increasing the share of net-zero or green buildings and financial incentives to build net-zero or green buildings. Financial incentives help push innovative and green building 
designs and technologies into the marketplace, while targets help pull these new designs and technologies into the market so that they become more commonly used. In terms of target-setting, the European Union has required its member states to ensure that all new buildings are nearly zeroenergy buildings by 2020, and the US states of California and Massachusetts have committed to achieving zero net energy for all new buildings by 2030 . California's "Savings by Design" program is one example of financial incentives provided to building design teams to encourage high performance, innovative commercial building design that maximizes energy savings (CPUC, 2013).

Similarly, the city of Seattle was the first US city to adopt a green building policy in 2000 and has since implemented a suite of green building policies including mandatory green building standards as well as financial, regulatory, and zoning incentives for certified green buildings. In 2011, Seattle adopted a Sustainable Buildings \& Sites Policy requiring all new construction and major renovations of $5000 \mathrm{ft}^{2}$ or greater to meet the Leadership in Energy and Environmental Design (LEED) Gold certification. ${ }^{5}$ From 2001 to 2005, the city provided more than US\$4.3 million in financial incentives for LEED-certified projects with average energy savings of 35\% (C40 Cities, 2014; WWF Global, 2012). In 2006, the city also began offering a density bonus incentive of greater height and/or greater maximum floor area for downtown commercial and residential buildings that meet LEED ratings of Silver or higher. Lastly, Seattle's Priority Green program provides streamlined and expedited permitting for green building project applicants (City of Seattle, 2014).

\subsubsection{Worker training and public outreach for low carbon residential buildings}

Training and public outreach is especially important for the buildings sector, which has the challenge of disseminating information on frequently changing techniques and technologies among numerous small-scale participants. A well-trained workforce is crucial to energy efficiency audits, retrofits, installations of renewable building applications, and design and operation of efficient and green buildings that have increasingly sophisticated controls. While most workforce development programs offer short-term training, there is a need for longer-term, broad education training on low carbon building. Training for homeowners, construction workers, and building energy specialists must track changing market conditions, engage small to medium sized firms, garner funding for workforce development programs, and give attention to coordinating and sustaining partnerships.

Kansas City, Missouri, offers an example of worker training and outreach. ${ }^{6}$ As one of the country's most economically challenged areas, Kansas City received
US\$20 million in seed funding from the US Department of Energy's Better Buildings Neighborhood Program to promote energy efficiency and workforce development and training programs. As part of the program, EnergyWorks $\mathrm{KC}$ is creating new job opportunities where they are needed most, by increasing demand for upgrades and training a workforce to adequately meet that demand. For example, the Metropolitan Energy Center provides Building Performance Institute certification training to energy efficiency professionals. Kansas City also provided training to approximately 45 energy efficiency contractors, with a focus on marketing and sales to improve their business models.

The city of San Diego provides another example of a training program for energy and carbon saving in residential buildings. The city provides local residents access to a free training program in green building technology through the dedicated Sustainable Training and Resource Center. ${ }^{7}$ This facility includes a weatherization simulation used for energy auditing with high tech infrared monitors; insulation demonstrations and applications; solar panel installation and maintenance; classroom facilities with a "tell-tale" pressure house to demonstrate energy savings and building envelope efficiencies; and a mobile weatherization lab, which takes training off site to any location in Southern California. A 5week program is designed to prepare students for entry-level work in the field or to enroll in further specialized training for HVAC mechanics, technicians, or installers; building performance or retrofit specialists; building control system technicians; energy auditors or home energy raters; and solar PV installers. The program is intended to help displaced workers, new workforce entrants, military veterans, and older outof-school youths. Funding for this effort, totaling US\$1.6 million comes from the American Recovery and Reinvestment Act, grants from the state Energy Program, Workforce Investment Act, and state Energy Sector Partnership. An additional US $\$ 700,000$ has been leveraged from contributing partners.

\subsection{Industrial sector}

Urban industry remains a significant energy consumer, even as cities seek an economic structure with high-performing, low-carbon service sectors. While decarbonization measures are relatively new for industry, industry and governments have a great deal of experience with energy conservation and efficiency measures. Measures such as energy audits and assessments gather essential information, while benchmarking measures track progress and provide external comparison. Energy performance standards for industrial equipment and products are strengthened over time through such programs as Stretch Targets, Reach Targets, and Top 
Runner targets. Industrial energy plans target sector-wide energy and carbon savings, including efficiency and fuel switching. At a systems level, industry is involved in programs for material recycling and by-product synergy, and in the development of low-carbon industrial parks. Here we highlight two types of policies measures for urban industry: energy management and economic incentives.

\subsubsection{Energy Management Standards and Training}

Energy management standards are used to institutionalize continuous improvement in energy efficiency within industrial facilities. As varying industrial energy management programs developed around the world, the International Standardization Organization (ISO) initiated "ISO 50001: Energy management systems - Requirements with guidance for use" in 2008, to provide more standardized guidance. The ISO 50001 standard was published in 2011. Because many industrial facilities do not yet have a designated energy manager, training provided by a government agency or an industrial association or other qualified organization, is needed to ensure that the goal of continuous energy management is realized.

Whereas standards for industrial energy management are typically established at the national or international levels, implementation and enhancement by local government supports industry achievement of the standards. In 2008, Shandong Provincial Government published a provincial standard on energy management systems (DB/T 1013 Energy Management System-Requirements). This standard was piloted in eight provincial industrial enterprises since June 2008. In 2009, the Shandong government issued Guidelines on Building Energy Management System in Enterprises of Shandong Province, published Industrial Enterprises Energy Management System, and established consulting and evaluation expert teams. Also in 2009, China published its national energy management standard. After the ISO 50001 was published in 2011, the national standard was revised as the Management System for Energy-Requirements and User Guidance in 2012, in order to be compatible with the international standard. Shandong Province continued to provide training for energy managers and to assist industrial enterprises in establishing energy management systems during the 12th Five-Year Plan period (2011-2015), to support China's national Top 10,000 Program for industrial energy saving,

\subsubsection{Economic Incentives for Industrial Energy Efficiency}

Economic policy measures enable industrial companies to identify cost-effective and energy-efficient measures suitable for their operations. Economic measures include: subsidies for energy assessments that cover either a fixed amount or a percentage of the total energy assessment costs; low interest loans for investments in energy-efficient or low carbon technologies; and tax incentives, such as accelerated depreciation on purchased energy-efficient equipment, tax reductions, and tax exemptions for companies that implemented energy-efficient measures.

For example, Japan incentivized industrial companies to invest in large-scale energy-saving projects by subsidizing up to one-third of the total cost (with an upper limit per project of 500 million JPY) of purchased energy-efficient equipment (Ayako, 2000). In the United States, low interest loans were provided in local energy efficiency programs, such as under the Energy Efficiency Revolving Loan Fund in New Jersey. Under this program, low interest-rate loans were provided to large energy users, and small-scale combined heat and power, with amounts range from US\$250,000 to 2.5 million. Interest rates vary with loan terms of 3 years (2\%), 5 years (3\%), and 7 years (4\%). In South Africa, companies can earn a tax break by providing evidence of energy efficiency savings. To be qualified for the incentives, all projects need to be manufacturing related and must result in a minimum of $10 \%$ energy reduction in the year that the investment is realized (IIP, 2012). Companies in the United Kingdom and Denmark can receive a reduction in energy tax if negotiated energy-saving targets are met. Under the French AERES program, companies face a penalty fee if failing to meet the voluntary targets.

Innovative economic measures link end-use energy efficiency to energy supply. Differential electricity pricing sets both the rewards and penalties for industrial firms to improve demand-side management. While the supply-side policy is set nationally, the demand-side effects are local and require local implementation. China began implementing differential electricity pricing for energy-intensive industrial sectors in 2004. Targeted sectors included electrolytic aluminum, ferroalloy, calcium carbide, caustic soda, cement, and steel. Prices of electricity are set based on the energy intensity levels of industrial companies. As of 2006, 30 of the 33 provinces in China had implemented this policy, covering about 2500 industrial companies. During the period 2004-2006, a total of 1280 companies closed, invested in energy efficiency, or changed production process (Moskovitz et al., 2007). This policy was further adjusted to allow local governments to retain revenue collected through the program, providing stronger motivation for local implementation. Improvements could be obtained by strengthening monitoring, and by ear-marking revenue for further investment in energy and carbon savings.

Challenges in implementing economic measures include: preventing free-riders (companies that would implement 
energy-efficient technologies without incentives), reducing high transaction cost for processing incentives, and verifying technology adoption rates and energy savings.

\subsection{Decarbonizing city energy systems}

In keeping with the overarching theme of the Handbook of Clean Energy, we highlight policy measures for clean city energy systems and decarbonization of energy supply.

\subsubsection{Renewable and distributed energy in Denmark}

Denmark is an interesting case to illustrate the decoupling of GDP from GHG emissions during the past 30 years, as well as decarbonization of city energy systems. By focusing on energy efficiency and renewable energy development, the country has managed to reduce GHG emissions while the economy has grown by almost $80 \%$ from 1990 to 2010 (Nordic Energy Research, 2012). Owing to the fact that the country has little energy-intensive industry, decarbonizing the energy system is achieved mainly through renewable its energy supply, particularly electricity generation and heating.

Decentralized combined heat and power (CHP) is one of the most important strategies that Denmark has utilized to reduce its carbon emissions over several decades while fuel consumption has remained unchanged. Denmark has one of the highest shares of district heating in the world. Approximately $60 \%$ of its national heating demands is supplied with district heating. Today, more than $80 \%$ of Danish district heating and half of electricity demands in Denmark are produced at CHP plants, thus saving around $30 \%$ of fuel compared with separate generation of heat and power (Danish Energy Agency, 2012a). As shown in Figure 5, Denmark used to have only centralized CHP plants located in large cities in 1985. Since the end of the 1980s, the distribution of CHP has changed significantly toward widely decentralized local CHP, totaling around 670 centralized and decentralized CHP plants (Danish Energy Agency, 2012a). The largest plants are owned by large energy companies, whereas the smaller plants typically are owned by production companies, municipalities, or cooperative societies.

The widespread use of combined heat and power not only saves fuel, it also makes it possible to use clean fuels. Around $12 \%$ of all electricity produced in Denmark is produced from biomass and organic waste in CHP plants (Danish Energy Agency, 2012a). Besides, the combination of heat storage and CHP generation facilitates the integration of wind. District heating systems are able to absorb excess renewable electricity generation in electric boilers or in heat pumps. In contrast, when there is more demand for electricity in less windy times, the combined heat and power plants can generate power and store the district heating in heat accumulation tanks.

Denmark is well known for its high percentage of renewable electricity generation. In 2011, approximately $40 \%$ of electricity was produced from renewable energy sources, mainly from wind, biomass, and waste (Nordic

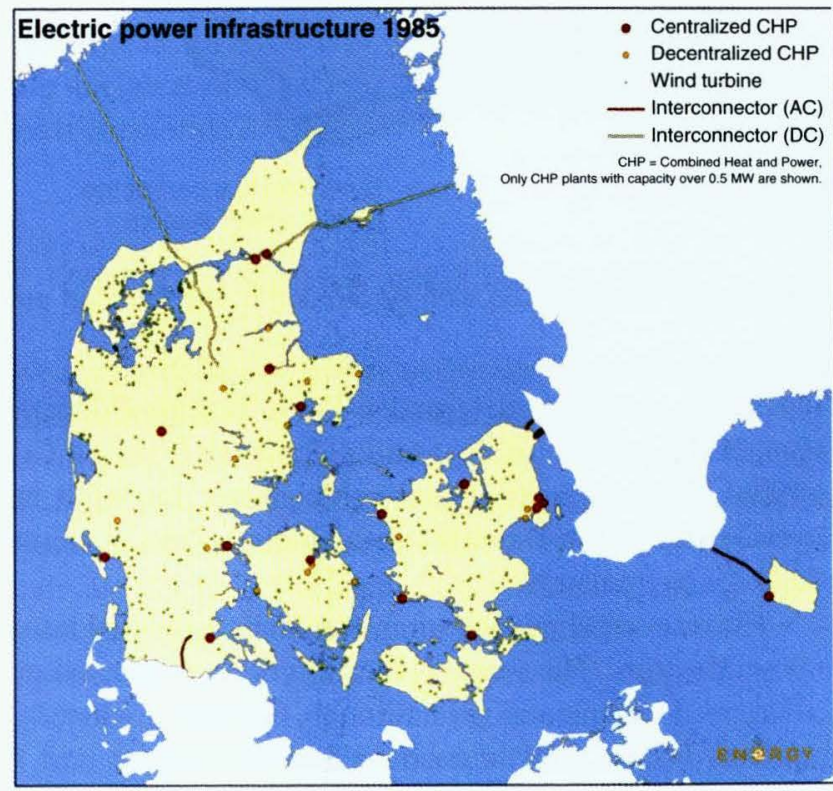

(a)

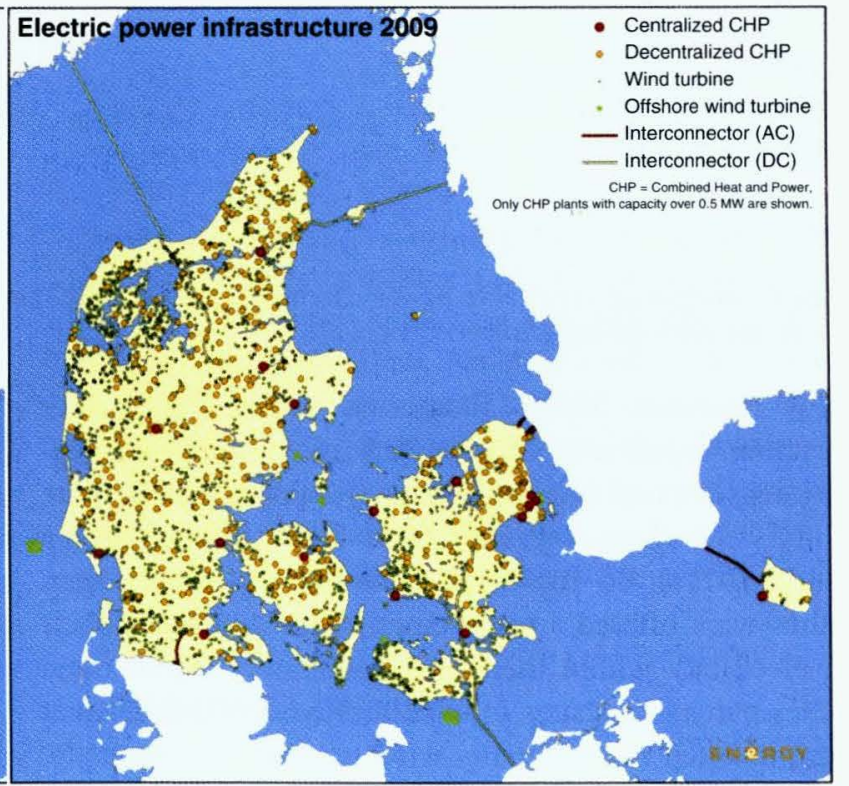

(b)

Figure 5. Distributed power: Danish power infrastructure in 1985 (a) and 2009 (b). Source: Reproduced with permission from Danish Energy Agency, 2012b. (C) Danish Energy Agency. 


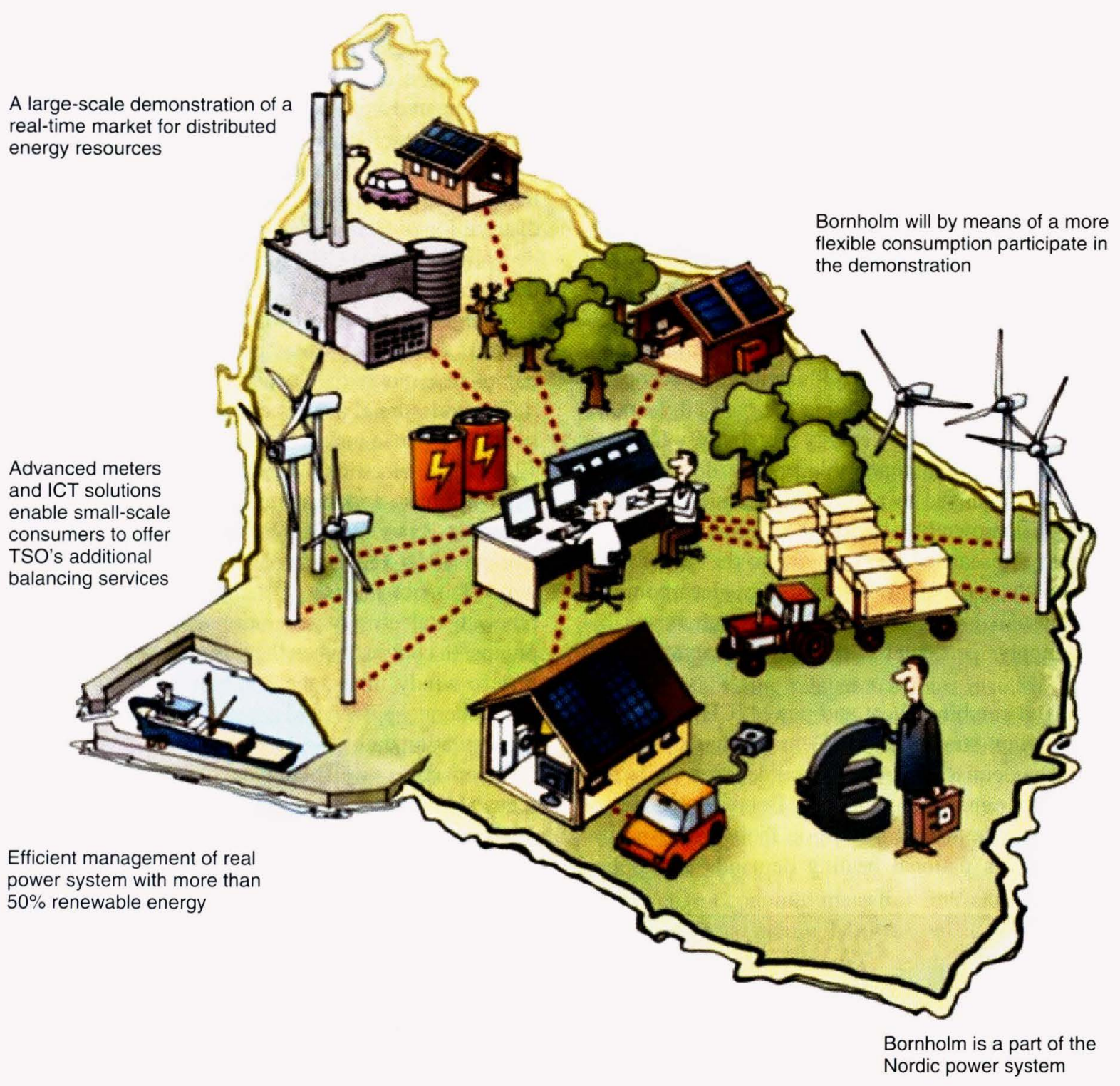

Figure 6. Integrating renewable power: Bornholm EcoGrid EU project. Source: Reproduced with permission of the EcoGrid project Consortium: www.eu-ecogrid.net. (c) EcoGrid.

Energy Research, 2012). Today, the annual wind power production supplies more than $30 \%$ of the national electricity consumption and it is estimated to provide $50 \%$ of the country's electricity consumption by 2020 (Danish Energy Agency, 2012c). To encourage investment in wind power, families were offered a tax exemption for generating their own electricity within their own community. More often families purchased shares in wind turbine cooperatives that in turn invested in community wind turbines. For example, the largest wind cooperative in the world is Middelgrunden offshore wind farm located approximately $2 \mathrm{~km}$ offshore from Copenhagen. The offshore wind farm consisting of 20 offshore wind turbines is $50 \%$ owned by the 10,000 investors in the Middelgrunden Wind Turbine Cooperative and $50 \%$ by the municipal utility company (State of Green, 1996). The cooperative ownership model for wind farms was developed in Denmark and widely spread in Germany and the Netherlands.

The transmission network in Denmark is divided into two separate grids. The western Danish grid is connected to the European continental grid through Germany, whereas the eastern Danish grid is connected to the Nordic grid with Norway and Sweden. The two areas have been connected through a $600 \mathrm{MW}$ DC connection across the Great Belt (ABB, 2011). The Danish power grid is set up to prioritize renewable energy before fossil fuels. Furthermore, Denmark 
has an energy control center that is responsible for forecasting and integrating as much renewable electricity as possible. Although Denmark already has a very flexible electricity market to integrate as much as $40 \%$ of renewables into the power system, a new intelligent power grid is being developed to allow the integration of $100 \%$ renewable energy. It has a wide array of smart grid assets within test and demonstration and over 60 smart grid firms (Copenhagen Cleantech Cluster, 2011).

The Danish island of Bornholm hosts a number of R\&D projects involving electric cars, solar cells, energy-efficient construction projects, and the development of an intelligent electricity system-all of which aims to reduce carbon emissions (Figure 6). The EcoGrid EU project attempts to demonstrate that modern information and communication technology (ICT) and innovative market solutions can enable the operation of a power system with more than $50 \%$ renewable energy sources such as wind, biomass, and photovoltaic (PV). Specifically, the project aims to increase the participation of distributed energy resources, demonstrate a real-time electricity market, and exploit flexible electricity consumption, including 1900 electricity customers and up to 100 industry and commercial buildings (EcoGrid, 2013). All houses have meters to register the consumption of the electricity from minute to minute to be used in advanced demand forecast models. Furthermore, there is an online customer feedback system installed to inform and motivate customers to change their electricity consumption behaviors according to the variations of electricity prices. All houses have heat pumps or electric heating, and all respond autonomously to price signals. In 2012, solar cells, wind turbines, and woodchip incineration met almost $50 \%$ of the island's energy needs (EcoGrid, 2013).

\section{CONCLUSIONS AND OUTLOOK}

Even as the definition of low carbon development is evolving, cities around the world are choosing metrics, conducting inventories, setting targets, launching policy measures, and taking action. Information exchange among cities-whether one-to-one or as part of regional and international consortia such as ICLEI, C40, and CDP-is contributing to the development of comparable methodologies and exchange of experience. Subsectoral metrics, such as energy per personkilometer in the transportation sector, not only help cities to benchmark performance with each other, such metrics also help identify energy and carbon saving measures. Inventories that gather detailed data on activities, energy, and economy, as well as carbon, better inform targets and measures. Wider use of the low carbon metrics and methodologies summarized here, over a longer period of measurement, will help track progress and yield insight for future measures.

From the city examples noted in the chapter, we see some common challenges as well as a rich variety of city structures and circumstances. The urban form of a city-its development patterns, zoning, density, and infrastructure design-has a profound influence on city carbon, particularly on the transportation sector. Low carbon urban design, including neighborhood retrofits as well as requirements for new development, is an essential strategy for reducing transportation emissions. With urban form as the foundation, other transportation measures can contribute further energy and carbon savings: prioritization of people and bicycles on complete streets, enhancement of public transit systems including BRT, and for the vehicles that remain, improved efficiencies and alternative energy sources.

City buildings, whether residential, commercial, or public, typically account for one-quarter to one-half of city GHG emissions. Cities have the authority to push for significant savings through net-zero energy (or carbon) buildings in new construction, as well as gradually implementing retrofit of existing building stock. Supporting measures and financial incentives help successful implementation and include energy audits, tax breaks on investments in energy efficiency or building-scale renewable energy systems, and expedited permitting.

The innovation occurring in city-level low carbon development is encouraging, yet much more effort is needed. Making a stronger connection between low carbon measures and economic development measures can surely help garner support and leverage funding. Adopting a systems view of energy can help cities better prioritize measures and distinguish between incremental improvements-such as installing energy-efficient windows - and more significant structure-changing measures-such as net-zero energy buildings with passive heating and cooling, clustered in a mixed-use neighborhood of walkable destinations. Analysis and policy measures to address life-cycle energy and carbon is an emerging direction. Another trend in low carbon city development is integration of climate resiliency, air quality improvement, and other environmental and ecological goals, with energy and carbon saving. Finally, cities are first and foremost places where people live. Any efforts at low carbon development must also contribute to social well-being to be successful.

\section{ACKNOWLEDGMENT}

Some of the work referred to in this chapter was supported by the China Sustainable Energy Program of the Energy Foundation through the US Department of Energy under Contract No. DE-AC02-05CH11231. 
This chapter has been authored by authors and affiliates of Lawrence Berkeley National Laboratory related to work under Contract No. DE-AC02-05CH11231 with the US Department of Energy. The US Government retains, and the publisher, by accepting the article for publication, acknowledges, that the US Government retains a nonexclusive, paidup, irrevocable, world-wide license to publish or reproduce the published form of this chapter, or allow others to do so, for US Government purposes.

\section{ENDNOTES}

1. For more information on the $\mathrm{C} 40$ Cities Climate Leadership Group, see http://www.c40.org/.

2. Methodology and rankings of the Green City Index, developed by Siemens, is available at http://www.siemens.com/entry/cc/en/greencityindex. htm.

3. For more about ICLEI initiatives and tools, see http://www.icleiusa.org/action-center/planning/climateaction-planning.

4. For a video summary of sustainability and economic development achievements in the city of Curitiba, Brazil, see http://www.ted.com/talks/jaime_ lerner_sings_of_the_city.html.

5. LEED is a voluntary green building certification and rating program administered by the US Green Building Council, with four certification levels of LEED certified (lowest), Silver, Gold, and Platinum (highest).

6. For more information about the example of building workforce training in Kansas City, see the case study by US DOE Energy Efficiency and Renewable Energy (EERE) division: http://www 1.eere.energy.gov/buildings/betterbuildings/ neighborhoods/kansas_city_profile.html.

7. For more information about the green building training program in the City of San Diego, California, see http://www.sdce.edu/organization/news/free-trainingprogram-green-building-technology.

\section{RELATED CHAPTERS}

Volume 4, Chapter 15

Volume 6, Chapter 6

Volume 6, Chapter 9

Volume 6, Chapter 31

Volume 6, Chapter 33

Volume 6, Chapter 34

Volume 6, Chapter 35

\section{REFERENCES}

A Convenient Truth: Urban Solutions from Curitiba (2007). Maria Vaz Photography, Del Bello Pictures [film].

ABB (2011) Connecting Denmark's Eastern and Western Power Grids: Storebaelt HVDC Submarine and Underground Cable Link, http://www05.abb.com/global/scot/scot245.nsf/veritydisplay/ b578b01b0879d50fc125777c0032cc1b/\$file/project\%20storebaelt $\% 20400 \% 20 \mathrm{kv} \% 20 \mathrm{mi} \% 20$ subm-land.pdf (accessed 14 October 2014).

ADEME [Agence de l'Environnement et de la Martrise de l'Energie] (2007) Bilan Carbone, Version 5.0, Methodological Guide for Companies and Local Authorities, www.ademe.fr/bilan-carbone (accessed 14 October 2014).

Athens, L. (2010) Building an Emerald City: A Guide to Creating Green Building Policies and Programs, Island Press, Washington, DC.

Ayako, S. (2000) Part III: promotion of energy efficiency investments in Japan. Promotion of energy efficiency in industry and financing of investments. United Nations. http://www.unescap.org/ esd/publications/energy/finance/part3_sato.html\#3.3.

C40 Cities Climate Leadership Group (2014) Case Study: Seattle Sets the Standards for Green Buildings, http://c40.org/c40cities/seattle/city_case_studies/seattle-setsthe-standards-for-green-buildings (accessed 14 October 2014).

C40 Climate Initiative (2010) Mexico City: Fuel Efficient Taxis, http://www.c40cities.org/bestpractices/transport/mexicocity_taxi. jsp (accessed 14 October 2014).

California Air Resources Board (CARB) (2010) Local Government Operations Protocol for the Quantification and Reporting of Greenhouse Gas Emissions Inventories. Version 1.1. http://www.theclimateregistry.org/resources/protocols/localgovernment-operations-protocol/ (accessed 14 October 2014).

California Energy Commission (CEC) (2013) Building Energy Efficiency Standards: Frequently Asked Questions, http://www.energy.ca.gov/title24/2013standards/rulemaking/ documents/2013_Building_Energy_Efficiency_Standards_FAQ. pdf (accessed 14 October 2014).

California Energy Commission (CEC) (2014) Local Ordinances Exceeding the 2008 Building Energy Efficiency Standards, http://www.energy.ca.gov/title24/2008standards/ordinances/ index.html (accessed 14 October 2014).

California Public Utilities Commission (CPUC) (2013) Design Team Incentives, http://www.savingsbydesign.com/design-team (accessed 14 October 2014).

Carbon Disclosure Project (CDP) (2011) CDP Cities 2011: Global Report on C40 Cities, https://www.cdproject.net/ Documents/CDP-Cities-2011-Report.pdf (accessed 14 October 2014).

Carbon Disclosure Project (CDP) (2012) Measurement for Management: CDP Cities 2012 Global Report, including Special Report on C40 Cities. https://www.cdproject.net/Documents/CDP-Cities2011-Report.pdf.

Calthorpe, P. (2011) Urbanism in the Age of Climate Change, Island Press, New york.

Carbon Disclosure Project (CDP) (2013) Wealthier, Healthier Cities: How Climate Change Action is Giving Us Wealthier, Healthier Cities. CDP Cities 2013 Global Report. 
Chavez, M. (2010) Sustainability Planning Lessons from New York and Mayor Bloomberg, http://www.environmentalleader. com/2010/04/19/sustainability-planning-lessons-from-new-yorkand-mayor-bloomberg/ (accessed 14-Oct 2014).

Chester, M. and Horvath, A. (2010) Comparison of life-cycle energy and emissions footprints of passenger transportation in metropolitan regions. Atmospheric Environment, 44 (8), 1071-1079. DOI: 10.1016/j.atmosenv.2009.12.012

City of Chicago (2008) Climate Action Plan, http://www.chicagoclimateaction.org/.

City of Chicago (2010) Chicago Climate Action Plan - Progress Report 2008-2009, http://www.chicagoclimateaction.org/pages/ ccap_progress_report/81.php.

City of Chicago (2012) CliSustainable Chicago - Action Agenda 2015, www.cityofchicago.org/content/dam/city/progs/env/ SCYearlReport.pdf/.

City of Paris (2007) Paris Climate Protection Plan [Plan Parisien de lute contre le dereglement climatique], planclimat.paris.fr http://www.paris.fr/pratique/energie-plan-climat/le-plan-climatde-paris/p8413.

City of Portland and Multnomah County (2009) Climate Action Plan 2009. Portland, Oregon, http://www.portlandonline. com/bps/index.cfm?c=49989\& (accessed 14 October 2014).

City of Santa Monica (2014) Santa Monica Local Amendments to CalGreen Standards, http://www.smgov.net/Departments/ OSE/Categories/Green_Building/Code_Requirements.aspx (accessed 14 October 2014).

City of Seattle (2014) City Green Building: Public Policy Initiatives, http://www.seattle.gov/dpd/GreenBuilding/OurProgram/ PublicPolicyInitiatives/default.asp (accessed 14 October 2014).

Copenhagen Cleantech Cluster (2011) Denmark: A European Smart Grid Hub, http://issuu.com/cphcleantech/docs/smart_grid (accessed 14 October 2014).

Covenant of Mayors (2009) Baseline emissions inventory guidelines. European Commission, Part II, in How to Develop a Sustainable Energy Action Plan (SEAP) Baseline Emissions Inventory (BEI), Publications Office of the European Union, Luxembourg.

Danish Energy Agency (2012a) Denmark a Leading Player in Combined Heat and Power, http://www.ens.dk/sites/ ens.dk/files/politik/vedvarende-energisamarbejde-

kina/faktaark/Nyefaktaark/chp.pdf (accessed 14 October 2014).

Danish Energy Agency (2012b) Overview Map of the Danish Power Infrastructure in 1985 and 2009, http://www.ens.dk/en/ info/facts-figures/energy-info-maps/download-premade-maps (accessed 14 October 2014).

Danish Energy Agency (2012c) Accelerating Green Energy Towards 2020, http://www.ens.dk/sites/ens.dk/files/dokumenter/ publikationer/downloads/accelerating_green_energy_ towards_2020.pdf (accessed 14 October 2014).

EcoGrid (2013) EcoGrid EU: From Design to Implementation, http://www.eu-ecogrid.net/images/News/131004_ $\% 20$ edk\%20a4_ecogrid\%20eu\%20project_web.pdf (accessed 14 October 2014).

European Commission, Joint Research Centre (JRC) and PBL Netherlands Environmental Assessment Agency (2013)
Trends in global CO, emissions: 2013 Report. October. http://edgar.jrc.ec.europa.eu.

California Climate Action Registry (CCAR) (2009) General Reporting Protocol. Version 3.1. http://www.climateregistry.org/resources/docs/protocols/grp/ GRP_3.1_January2009.pdf (accessed 14 October 2014).

GRIP (2008) Greenhouse Gas Regional Inventory Protocol. Tyndall Centre for Climate Change Research, University of Manchester and UK Environmental Agency. http://www.getagriponemissions.com/index-cycle.html (accessed 14 October 2014).

GRIP (2009) Greenhouse Gas Inventories for 18 European Regions. Prepared by University of Manchester and METREX, May. http://www.euco2.eu/resources/GRIP-Broschuere-Small.pdf.

van der Hoeven, M. (2012) Urban Energy Policy Design. IEA News and Sustainable Cities 2012, http://www.iea.org/ newsroomandevents/news/2012/june/name,28079,en.html (accessed 14 Oct 2014).

Ibrahim, N., Sugar, L., Hoornweg, D., and Kennedy, C. (2012) Greenhouse gas emissions from cities: comparison of international inventory frameworks. Local Environment, 17 (2), 223-241.

ICF International (2010) Chicago 2010 Regional Greenhouse Gas Emissions Inventory. Prepared by ICF International for: Global Philanthropy Partnership with the City of Chicago and the Chicago Metropolitan Agency for Planning.

ICLEI (2010) Climate Program. International Council for Local Environmental Initiatives (ICLEI) - Local Governments for Sustainability. http://www.iclei.org/index.php?id=800.

ICLEI (2009) U.S. Mayors Climate Protection Agreement Climate Action Handbook. International Council for Local Environmental Initiatives (ICLEI) - Local Governments for Sustainability. http://iclei-usa.org:10080/mount_iclei/iclei/actioncenter/planning/climate-action-handbook.

ICLEI USA (2008) Community Greenhouse Gas Inventory Methodology for Bay Area Local Governments. International Council for Local Environmental Initiatives (ICLEI)—Local Governments for Sustainability USA. www.unioncity.ca.us/green_city/Green_city_PDFs/GHG\%20Methodology. pdf (accessed 14 October 2014).

Institute for Industrial Productivity (IIP) (2012) Industrial Efficiency Policy Database-ZA4: Energy Efficiency Tax Incentive Regulations, http://iepd.iipnetwork.org/policy/energy-efficiencytax-incentive-regulations (accessed 14 October 2014).

Intergovernmental Panel on Climate Change (IPCC) (1996) Revised 1996 IPCC Guidelines for National Greenhouse Gas Inventories (eds J.T. Houghton, L.G. Meira Filho, B. Lim, et al.), IPCC/OECD/IEA and UK Meteorological Office, Bracknel.

Intergovernmental Panel on Climate Change (IPCC) (2006) 2006 IPCC Guidelines for National Greenhouse Gas Inventories (eds S. Eggelston, L. Buendia, K. Miwa, et al.), Institute for Global Environmental Strategies (IGES), Hayama.

Intergovernmental Panel on Climate Change (IPCC) (2007) Summary for policymakers, in Climate Change 2007: Mitigation. Contribution of Working Group III to the Fourth Assessment Report of the Intergovernmental Panel on Climate Change (eds B. Metz, O.R. Davidson, P.R. Bosch, et al.), Cambridge University Press, Cambridge. http://www.ipcc.ch. 
International Energy Agency (IEA) (2013) Modernising Building Energy Codes to Secure our Global Energy Future OECD/IEA Press. http://www.iea.org/publications/ freepublications/publication/PP7_Building_Codes_2013_WEB. pdf.

Jacobs, J. (1993) The Death and Life of Great American Cities, Modern Library, New York. Modern Library ed. 1961 book with new forward by author.

Maher, A. (2013) The Rise of the 20-Minute Neighborhood. Initiative for a Competitive Inner City (ICIC). http://www.icic.org/connection/blog-entry/blog-the-rise-ofthe-20-minute-neighborhood.

Moffatt, S., Suzuki, H., Izuka, R. (2012) eCO ${ }^{2}$ Cities Guide: Ecological Cities as Economic Cities. World Bank. www.worldbank.org/eco2

Moskovitz, D., Lin, J., Weston, F., et al. (2007) Energy Conservation and Resource Management Project, Part A Final Report, TA 4706$P R C$, Asian Development Bank, Manila.

National Bureau of Statistics (NBS) (2009) China Energy Statistical Yearbook, China Statistics Press, Beijing (and various years).

National Development and Reform Commission (NDRC) (2006) NDRC Official Press Conference: Improve Differential Electricity Pricing and Accelerate the Industry Structural Adjustment, http://www.ndrc.gov.cn/xwfb/t20060930_87356.htm (accessed 14 October 2014).

New York City (2011) PlaNYC. April 2011 update to the 2007 Plan, http://www.nyc.gov/html/planyc2030/html/home/home.shtml (accessed 14 October 2014).

NYC DOT (2012) Measuring the Street: New Metrics for the 21st Century, http://www.nyc.gov/html/dot/downloads/pdf/201210-measuring-the-street.pdf.

Nordic Energy Research (2012) Danish GDP, Energy Use and Emissions, http://www.nordicenergy.org/ thenordicway/country/denmark/\#danish-leadership-indecoupling-economic-growth (accessed 14 October 2014).

Price, L., Zhou, N., Fridley, D., et al. (2012) Development of a lowcarbon indicator system for China. Habitat International. DOI: 10.1016/j.habitatint.2011.12.009

San Francisco Metropolitan Transportation Agency (SF MTA) (2011) Climate Action Strategy.

Snyder, T. (2013) 500+ Complete Streets Policies in Place, But Not the Most Important One. StreetsBlog USA. http://www.streetsblog.org/category/issues-campaigns/completestreets/ (accessed 16 August 2013).

Copenhagen Environment and Energy Office (2003) Middelgrunden Wind Turbine Cooperative. Booklet. Copenhagen Environment and Energy Office. http://hzs.ndrc.gov.cn/newzwxx/ t20110907_433096.htm (accessed 14-Oct 2014).

State of Green (1996) Middelgrunden Wind Turbine Cooperative, www. Middelgrunden.dk.

US Department of Energy (2014) Building Energy Codes Program: Model Policies for Code Adoption and Compliance, Exceeding the Code, http://www.energycodes.gov/resource-center/modelpolicy?f[0]=field_model_policy_category\%3A245 (accessed 14 October 2014).
US Environmental Protection Agency (US EPA) (2009) Inventory of U.S. Greenhouse Gas Emissions and Sinks: Fast Facts, http://epa.gov/climatechange/emissions/downloads1 1/GHG-FastFacts-2009.pdf (accessed 14 October 2014).

US Environmental Protection Agency (US EPA) (2013a) Emissions of Fluorinated Gasses. U.S. Environmental Protection Agency. http://epa.gov/climatechange/ghgemissions/gases/fgases.html.

US Environmental Protection Agency (US EPA) (2013b) Local Government-Developing a Greenhouse Gas Inventory. U.S. Environmental Protection Agency. http://epa.gov/statelocalclimate/local/activities/ghginventory.html.

UNEP et al. (2010) International Standard for Determining Greenhouse Gas Emissions for Cities, United Nations Environment Program (UNEP), United Nations Human Settlements Program (UN Habitat), and the World Bank. www.unep.org/urban_environment/PDFs/InternationalStdGHG.pdf.

UNFCCC (1997) The Kyoto Protocol, United Nations Framework Convention on Climate Change, Kyoto.

Urban, F. and Nordensvärd, J. (2013) Chapter 1: Low carbon development: Origins, concepts, and key issues in Low Carbon Development: Key Issues (eds F. Urban and J. Nordensvärd), Routledge, London.

Vance, S. (2013) Complete Streets Guidelines Codify Principles of Multi-Modal Streets, StreetsBlog.org. http://chi.streetsblog.org/2013/04/12/complete-streets-guidelinescodify-principles-of-multi-modal-streets/ (accessed 12 April 2013).

Wang, K. (2011) The Role of Cities in Meeting China's Carbon Intensity Goal. Part 1: China's Low-Carbon City Plans. Open Climate Network post on World Resources Institute blog. http://www.wri.org/blog/role-cities-meetingchina\%E2\%80\%99s-carbon-intensity-goal (accessed 14 October 2014).

World Bank (2010) Cities and Climate Change: An Urgent Agenda, http://siteresources.worldbank.org/INTUWM/Resources/3402321205330656272/CitiesandClimateChange.pdf (accessed 14 October 2014).

World Bank (2012) Sustainable Low-Carbon City Development in China (eds A. Baeumler, E. Ijjasz-Vasquez, and S. Mehndiratta), World Bank, Washington, DC.

World Business Council for Sustainable Development/World Resources Institute (WBCSD/WRI) (2004) The Greenhouse Gas Protocol: A Corporate Accounting and Reporting Standard (revised edition), http://www.ghgprotocol.org/standard/ GHGProtocolCorporateStandard_RevisedEdition.pdf (accessed 14 October 2014).

WRI et al. (2013) Global Protocol For Community-Scale Greenhouse Gas Emissions (GPC), WRI, ICLEI and C40 Cities Climate Leadership Group, supported by: World Resources Institute, World Bank, UNEP, and UN-HABITAT. http://www.ghgprotocol.org/city-accounting.

WWF Global (2012). Seattle: LEED-ing in Green Building, http://wwf.panda.org/what_we_do/footprint/cities/urban_ solutions/themes/housing/?204583/Seattle (accessed 1 March 2012). 
Zhou, N., Price, L., Ohshita, S., et al. (2011) A Guidebook for Low-Carbon Development at the Local Level, Lawrence Berkeley National Laboratory Berkeley, Berkeley. Report, 196 pp, http://china.lbl.gov/sites/all/files/lbl-5370e-low-carbonguidebookoct-2011.pdf.
Zhou, N., Price, L., Fridley, D., et al. (2012) Strategies for Local Low-Carbon Development, Lawrence Berkeley National Laboratory: Berkeley. Booklet, $55 \mathrm{pp}$, http://china.lbl.gov/publications/strategies-local-low-carbondevelopme. 